\title{
The Antiaging Protein Klotho Enhances Oligodendrocyte Maturation and Myelination of the CNS
}

\author{
Ci-Di Chen, ${ }^{1}$ Jacob A. Sloane, ${ }^{2 \star}$ Hu Li, ${ }^{3 \star}$ Nurgul Aytan, ${ }^{4 \star}$ Eustathia L. Giannaris, ${ }^{5 \star}$ Ella Zeldich, ${ }^{1}$ Jason D. Hinman, ${ }^{6}$ \\ Alpaslan Dedeoglu, ${ }^{4}$ Douglas L. Rosene, ${ }^{5}$ Rashmi Bansal, ${ }^{7}$ Jennifer I. Luebke, ${ }^{5}$ Makoto Kuro-o,${ }^{8}$ and \\ Carmela R. Abraham ${ }^{1}$ \\ ${ }^{1}$ Department of Biochemistry, Boston University School of Medicine, Boston, Massachusetts 02118, ${ }^{2}$ Department of Neurology, Beth Israel Deaconess \\ Medical Center, Boston, Massachusetts 02215, ${ }^{3}$ Department of Biomedical Engineering, Boston University, Boston, Massachusetts 02215, ${ }^{4}$ Department of \\ Neurology, Boston University School of Medicine and Veterans Administration Boston Healthcare System, Boston, Massachusetts 02130, ${ }^{5}$ Department of \\ Anatomy \& Neurobiology, Boston University School of Medicine, Boston, Massachusetts 02118, ${ }^{\circ}$ Department of Neurology, University of California Los \\ Angeles, Los Angeles, California 90095, ${ }^{7}$ Department of Neuroscience, University of Connecticut Medical School, Farmington, Connecticut 06030, and \\ ${ }^{8}$ University of Texas Southwestern Medical Center, Dallas, Texas 75390
}

We have previously shown that myelin abnormalities characterize the normal aging process of the brain and that an age-associated reduction in Klotho is conserved across species. Predominantly generated in brain and kidney, Klotho overexpression extends life span, whereas loss of Klotho accelerates the development of aging-like phenotypes. Although the function of Klotho in brain is unknown, loss of Klotho expression leads to cognitive deficits. We found significant effects of Klotho on oligodendrocyte functions, including induced maturation of rat primary oligodendrocytic progenitor cells (OPCs) in vitro and myelination. Phosphoprotein analysis indicated that Klotho's downstream effects involve Akt and ERK signal pathways. Klotho increased OPC maturation, and inhibition of Akt or ERK function blocked this effect on OPCs. In vivo studies of Klotho knock-out mice and control littermates revealed that knock-out mice have a significant reduction in major myelin protein and gene expression. By immunohistochemistry, the number of total and mature oligodendrocytes was significantly lower in Klotho knock-out mice. Strikingly, at the ultrastructural level, Klotho knock-out mice exhibited significantly impaired myelination of the optic nerve and corpus callosum. These mice also displayed severe abnormalities at the nodes of Ranvier. To decipher the mechanisms by which Klotho affects oligodendrocytes, we used luciferase pathway reporters to identify the transcription factors involved. Together, these studies provide novel evidence for Klotho as a key player in myelin biology, which may thus be a useful therapeutic target in efforts to protect brain myelin against age-dependent changes and promote repair in multiple sclerosis.

\section{Introduction}

Klotho is an antiaging protein named after the mythical Greek goddess who "spins the thread of life" (Kuro-o et al., 1997). Klotho knock-out mice exhibit many changes that also frequently

\footnotetext{
Received April 30, 2012; revised Nov. 19, 2012; accepted Dec. 4, 2012.

Author contributions: C.-D.C., J.A.S., R.B., and C.R.A. designed research; C.-D.C., J.A.S., N.A., E.L.G., E.Z., J.D.H., and J.I.L. performed research; A.D. and M.K-0. contributed unpublished reagents/analytic tools; C.-D.C., J.A.S., H.L., N.A., E.L.G., J.D.H., and C.R.A. analyzed data; C.-D.C., J.A.S., J.D.H., D.L.R., J.I.L., and C.R.A. wrote the paper.

This work was supported by National Institutes of Health NIA Grant AG-00001, an ADDF Award to C.R.A., National Institutes of Health NINDS R25 Training Grant to J.D.H., a National Multiple Sclerosis Society Research Grant to J.A.S. and an Ellison Foundation Award to C.-D.C. We thank Dr. Alan Peters for help in interpretation of the electron microscopy data; Drs. Yuriy Alekseyev and Marc Lenburg for help with the microarray analysis; Drs. Sha Mi, Paul Rosenberg, and Jianlin Wang for help with the early rat OPC preparations; Dr. Cindy Lemere and Jeffrey Frost for the mice samples and help in isolating mouse brain tissues; Dr. Rong Fan for help in preparing Klotho mice brain tissue homogenates; Chun-Tsin Hsu for assistance with the qRT-PCR experiments; Dr. Matt Rasband for sharing of antibody reagents; and Drs. Gwendalyn King, James J. Collins, Ji-Hye Paik, Ido Wolf, and Tami Rubinek for critical review of and suggestions for this manuscript.

The authors declare no competing financial interests.

*J.A.S., H.L., N.A., and E.L.G. contributed equally to this work.

Correspondence should be addressed to Dr. Carmela R. Abraham, Department of Biochemistry, Boston University

School of Medicine, 72 E. Concord Street, K304, Boston, MA 02118. E-mail: cabraham@bu.edu.

DOI:10.1523/JNEUROSCI.2080-12.2013

Copyright $\odot 2013$ the authors $\quad 0270-6474 / 13 / 331927-13 \$ 15.00 / 0$
}

occur during human aging, including arteriosclerosis, osteoporosis, and cognitive decline. The mice develop normally but die prematurely, with an average life span of $\sim 61 \mathrm{~d}$ (Kuro-o et al., 1997), whereas mice overexpressing Klotho live 30\% longer than wild-type mice (Kurosu et al., 2005). In early adulthood, Klotho knock-out mice show memory retention deficits (Nagai et al., 2003), a reduction in synapses in the hippocampus ( $\mathrm{Li}$ et al., 2004), perturbations in axonal transport, and a neurodegenerative phenotype in the hippocampus (Shiozaki et al., 2008). Interestingly, humans carrying the Klotho-VS polymorphism exhibit reduced cognitive abilities (Nagai et al., 2003; Deary et al., 2005), as well as reduced life span (Nagai et al., 2000; Arking et al., 2003; Arking et al., 2005). The basis of cognitive deficits in Klotho knock-out mice or in humans with Klotho-VS polymorphism is not known, and a more thorough assessment of neuropathology is needed.

Klotho is highly expressed in the choroid plexus and neurons, especially in the hippocampus, as well as in the kidney and reproductive organs (Kuro-o et al., 1997), but its function in the brain is not clear. Klotho is a type I transmembrane protein cleaved by ADAM10 and 17 from the cell membrane (Chen et al., 2007; 
Bloch et al., 2009) and is detectable in serum and CSF (Imura et al., 2004). Klotho functions include regulation of FGF23 signaling, suppression of the insulin/IGF1 and Wnt signaling pathways, and regulation of calcium and phosphate homeostasis (Kuro-o, 2010). In contrast to other organ systems, none of the downstream effects of Klotho has been studied for the CNS and little is known regarding the downstream signal transduction machinery required for Klotho's CNS effects. Considering the distribution of Klotho expression and processing within the CNS and the effects on cognition cited above, Klotho is positioned to influence a variety of CNS structures and functions in development and aging.

As part of our studies of age-associated cognitive decline in the rhesus monkey, we discovered using microarray analysis that Klotho expression was decreased in the aged corpus callosum (Duce et al., 2008), probably because of the hypermethylation of its promoter (King et al., 2012). This is of interest as damage to myelin is ubiquitous in aging monkey brain (Kohama et al., 2011) at biochemical (Sloane et al., 2003), ultrastructural (Bowley et al., 2010), and macroscopic levels (Makris et al., 2007; Wisco et al., 2008), and these abnormalities are often associated with cognitive decline (Hinman and Abraham, 2007; Peters, 2009). To determine whether there is a connection between age-related alterations in Klotho expression (Duce et al., 2008) and CNS dysmyelination (Sloane et al., 2003; Hinman and Abraham, 2007), and to understand the functions of Klotho in the brain, we assessed how Klotho influences oligodendrocyte function and developmental myelination and describe here the important and novel role Klotho plays in oligodendrocyte biology and myelination.

\section{Materials and Methods}

Materials. The recombinant mouse Klotho protein containing the extracellular domain of mouse Klotho (Ala 35-Lys 982) was from R\&D Systems. Akt inhibitor LY294002 and ERK inhibitor UO126 were from Cell Signaling Technology. Growth factors for oligodendrocytes were from Peprotech. All other chemicals were from Sigma-Aldrich.

Animal tissue and protein sample preparation. Klotho knock-out (Kuro-o et al., 1997) and control mice were perfused with $0.1 \mathrm{M} \mathrm{PBS,} \mathrm{pH}$ 7.4 , at $4^{\circ} \mathrm{C}$ and hemibrains homogenized in $5 \times(\mathrm{v} / \mathrm{w})$ ice-cold RIPA buffer with protease and phosphatase inhibitor cocktails (Roche) (King et al., 2012). Samples were then centrifuged at $16,000 \times g$ for $15 \mathrm{~min}$, and the supernatant was collected for SDS-PAGE and Western blot analysis.

Oligodendrocyte progenitor cell (OPC) cultures. OPCs were isolated from female Sprague Dawley postnatal day 2 rat pups as described previously (Mi et al., 2005; Sloane and Vartanian, 2007). Cultures were maintained in high-glucose DMEM OPC culture medium $(4 \mathrm{~mm}$ L-glutamine, $1 \mathrm{~mm}$ sodium pyruvate, $0.1 \% \mathrm{BSA}, 50 \mu \mathrm{g} / \mathrm{ml}$ insulin, $30 \mathrm{~nm}$ sodium selenite, $10 \mathrm{~nm}$ D-biotin, and $10 \mathrm{~nm}$ hydrocortisone) containing bFGF/PDGF (10 ng/ml) for 1-3 d and replaced with either DMEM medium with CNTF $(10 \mathrm{ng} / \mathrm{ml})$, T3 (15 nM), and NT3 $(10 \mathrm{ng} / \mathrm{ml})$, or DMEM with CNTF and NT3 alone, with or without recombinant mouse Klotho at a concentration of $0.4 \mu \mathrm{g} / \mathrm{ml}$ at $37^{\circ} \mathrm{C}$ for $3-8 \mathrm{~d}$, as indicated in the figures. Half of the medium bathing the cells was replaced with fresh medium with or without Klotho every other day. The same concentration of Klotho was used in all experiments. The cell lysates were collected in RIPA buffer as described previously, and protein samples were analyzed by SDS-PAGE and Western blotting.

Western blotting. Protein concentrations were measured using the Micro BCA Protein Assay Reagent Kit (Pierce) according to the manufacturer's protocol. For SDS-PAGE, cell lysates containing the same amount of total protein were boiled for $5 \mathrm{~min}$ and loaded on $4-20 \%$ precast Tris-Glycine gels (Bio-Rad). Proteins were transferred to nitrocellulose membranes (Millipore). All antibodies were diluted in TBST (50 mM Tris, $\mathrm{pH} 8.0,150 \mathrm{~mm} \mathrm{NaCl}$, and $0.1 \%(\mathrm{v} / \mathrm{v})$ Tween 20 ) containing $5 \%$ $(\mathrm{w} / \mathrm{v})$ nonfat dry milk. Secondary antibodies were horseradish peroxidase-
Table 1. Myelin-related genes used in qPCR analysis comparing gene expression of Klotho $^{-/-}$and Klotho ${ }^{+/+}$mice brain samples at 8 weeks of age

\begin{tabular}{llll}
\hline Symbol & Description & Fold change $^{a}$ & $p$ \\
\hline Aspa & Aspartoacylase & -1.99 & $0.0374^{b}$ \\
CNP & $2^{\prime}, 3^{\prime}$-cyclic nucleotide 3' phosphodiesterase & $-2.26^{b}$ & $0.0419^{b}$ \\
EDG2 & Lysophosphatidic acid receptor 1 & $-2.18^{b}$ & $0.0271^{b}$ \\
Enpp2 & Ectonucleotide pyrophosphatase/phosphodiesterase 2 & -1.73 & $0.0345^{b}$ \\
Erbb3 & v-erb-b2 erythroblastic leukemia viral oncogene & -1.92 & $0.0196^{b}$ \\
& $\quad$ homolog 3 & & \\
Klk6 & Kallikrein-related peptidase 6 & $-7.35^{b}$ & $0.0237^{b}$ \\
MAG & Myelin-associated glycoprotein & $-3.97^{b}$ & $0.0266^{b}$ \\
MBP & Myelin basic protein & $-4.68^{b}$ & $0.0189^{b}$ \\
MAL & Myelin and lymphocyte protein, T-cell differentiation & $-2.09^{b}$ & $0.0479^{b}$ \\
& $\quad$ protein & & \\
MOBP & Myelin-associated oligodendrocytic basic protein & $-3.15^{b}$ & $0.0132^{b}$ \\
MOG & Myelin oligodendrocyte glycoprotein & $-2.88^{b}$ & $0.0045^{b}$ \\
Olig2 & Oligodendrocyte transcription factor 2 & -1.54 & 0.1581 \\
Pllp & Plasma membrane proteolipid & $-2.26^{b}$ & $0.0051^{b}$ \\
Plp1 & Proteolipid protein (myelin) 1 & $-2.30^{b}$ & $0.0097^{b}$ \\
Pmp22 & Peripheral myelin protein 22 & $-3.94^{b}$ & 0.0715 \\
\hline
\end{tabular}

${ }^{a}$ Fold change represents $\mathrm{Klotho}^{-/-}$compared with Klotho ${ }^{+/+}$as control. $N=4$ for each group.

${ }^{b} p<0.05$ and fold change $>-2$.

conjugated goat anti-mouse, anti-rat, or anti-rabbit (1:5000, Kirkegaard \& Perry Laboratories). Enhanced chemiluminescence was detected using Immobilon Western Chemiluminescent Substrate (Millipore). Autoradiography was done using Kodak Scientific Imaging Film X-OMAT AR (Eastman Kodak).

The primary antibodies used were as follows: anti-myelin basic protein (MBP) mouse monoclonal antibody (1:1000, Covance), anti-myelinassociated glycoprotein (MAG) mouse monoclonal antibody (clone B11F7, 1:1000), anti-2' $3^{\prime}$ 'cyclic nucleotide-3' -phosphodiesterase mouse monoclonal antibody (1:1000, Sigma), anti-FGF receptor substrate (FRS) Y196 (1:1000, Cell Signaling Technology), anti-OSP rabbit polyclonal antibody (1:1000, Abcam), anti-proteolipid protein (PLP) mouse monoclonal antibody (1:1000, Millipore), anti-PCNA clone PC10 (1: 1000 , Millipore), and anti- $\beta$-tubulin monoclonal antibody (1:1000, Invitrogen). The antibodies in the Akt and ERK pathways were from phospho Akt and ERK pathway kit (Cell Signaling Technology) and were used according to the manufacturer's protocol.

$q R T-P C R$. Total RNA was isolated using QIAGEN's RNeasy kit (QIAGEN). A reverse transcription was performed with $2 \mu \mathrm{g}$ of total RNA from each sample. Primers for selected mouse myelin-related genes (see Table 1) and corresponding rat oligodendrocyte maturation-enriched genes as published previously (Cahoy et al., 2008) were designed by RealTimePrimers. Controls included $\beta$ actin, $\beta-2$ microglobulin, phosphoglycerate kinase 1 , hypoxanthine phosphoribosyltransferase 1 , and GAPDH. The qRT-PCR experiments were performed with iQ SYBR Green Supermix (Bio-Rad) with detection on a Bio-Rad C1000 Thermal Cycler. The whole cDNA from $2 \mu \mathrm{g}$ of total RNA was used for one 96-well plate. Triplicates of $20 \mu \mathrm{l}$ reactions containing primer and cDNA template were used for quantitation. A PCR was carried out as follows: 1 cycle of $95^{\circ} \mathrm{C}$ for $3 \mathrm{~min}$ followed by 40 cycles of $95^{\circ} \mathrm{C}$ for $10 \mathrm{~s}, 55^{\circ} \mathrm{C}$ for $20 \mathrm{~s}$, and $72^{\circ} \mathrm{C}$ for $30 \mathrm{~s}$. This was followed by a dissociation curve beginning at $55^{\circ} \mathrm{C}$ and increasing by $0.2^{\circ} \mathrm{C}$ every $3 \mathrm{~s}$, with SYBR Green fluorescence measured at every interval. Relative quantitation of the difference between the control and Klotho-treated samples was done using $\mathrm{RT}^{2}$ Profiler PCR Array Data Analysis Program (QIAGEN). Genes were tested for statistical significance $(p<0.05)$, relative to the control, by Student's $t$ test.

Luciferase assay. Paired homeodomain protein 3 (Pax3) reporter plasmid (pluc-TKCD-19) was kindly provided by Dr. Frank Rauscher III (Wistar Institute, Philadelphia, Pennsylvania). Signal Transduction 45 pathway Reporter Array (see Tables 2 and 3) was from SABiosciences (QIAGEN). OPCs were plated into 96-well plates at a density of $0.65 \times$ $10^{6}$ cells/plate in OPC culture medium containing bFGF/PDGF for $3 \mathrm{~d}$ before transfection. A total of $200 \mathrm{ng}$ of Luciferase reporter or control empty-vector DNA (with 5 ng Renilla luciferase) was transfected into 
Table 2. Signal transduction 45-pathway reporter array

\begin{tabular}{|c|c|c|}
\hline Reporter & Pathway & Transcription factor \\
\hline AARE & Amino acid deprivation response & ATF4/ATF3/ATF2 \\
\hline AR & Androgen receptor & Androgen receptor \\
\hline ARE & Antioxidant response & Nrf2 and Nrf1 \\
\hline ATF6 & ATF6 & ATF6 \\
\hline C/EBP & C/EBP & C/EBP \\
\hline CRE & CAMP/PKA & CREB \\
\hline $\mathrm{E} 2 \mathrm{~F}$ & Cell cycle & E2F/DP1 \\
\hline p53 & p53/DNA damage & p53 \\
\hline EGR1 & EGR1 & EGR1 \\
\hline ERSE & Endoplasmic reticulum stress & CBF/NF-Y/YY1 \\
\hline ERE & Estrogen receptor & Estrogen receptor \\
\hline GATA & GATA & GATA \\
\hline GRE & Glucocorticoid receptor & Glucocorticoid receptor \\
\hline HSR & Heat shock response & HSF \\
\hline MTF1 & Heavy metal stress & MTF1 \\
\hline GLI & Hedgehog & GLI \\
\hline HNF4 & Hepatocyte nuclear factor 4 & HNF4 \\
\hline HIF & Hypoxia & HIF-1 \\
\hline IRF1 & Interferon regulation & IRF1 \\
\hline ISRE & Type I interferon & STAT1/STAT2 \\
\hline GAS & Interferon $\gamma$ & STAT1/STAT1 \\
\hline KLF4 & KLF4 & KLF4 \\
\hline LXR & Liver X receptor & LXRa \\
\hline SRE & MAPK/ERK & Elk-1/SRF \\
\hline AP1 & MAPK/JNK & AP-1 \\
\hline MEF2 & MEF2 & MEF2 \\
\hline Myc & c-myc & Myc/Max \\
\hline Nanog & Nanog & Nanog \\
\hline RBP-Jk & Notch & RBP-Jk \\
\hline $\mathrm{NF} \kappa \mathrm{B}$ & $\mathrm{NF} \kappa \mathrm{B}$ & $N F \kappa B$ \\
\hline 0ct4 & Oct4 & Oct4 \\
\hline Pax6 & Рax6 & Pax6 \\
\hline FOXO & PI3K/AKT & FOXO \\
\hline NFAT & $\mathrm{PKC} / \mathrm{Ca}^{2+}$ & NFAT \\
\hline PPAR & PPAR & PPAR \\
\hline PR & Progesterone receptor & Progesterone receptor \\
\hline RARE & Retinoic acid receptor & Retinoic acid receptor \\
\hline RXR & Retinoid X receptor & Retinoid X receptor \\
\hline Sox2 & Sox2 & Sox2 \\
\hline SP1 & SP1 & SP1 \\
\hline STAT3 & STAT3 & STAT3 \\
\hline SMAD & $\mathrm{TGF} \beta$ & SMAD2/SMAD3/SMAD4 \\
\hline VDR & Vitamin D receptor & Vitamin D receptor \\
\hline TCF/LEF & Wnt & TCF/LEF \\
\hline XRE & Xenobiotic & AhR \\
\hline
\end{tabular}

Table 3. Transcriptional regulatory element sequence information of the luciferase reporters involved in Klotho-dependent responses in OPCs

\begin{tabular}{lll}
\hline Reporter & Pathway & Transcriptional regulatory element sequence \\
\hline AP1 & MAPK/JNK & TGAGTCAG \\
ARE & Antioxidant response & AACATTGCATCATCCCCGC \\
C/EBP & C/EBP & ATTGCGCAAT \\
LXR & Liver $X$ receptor & TGAATGACCAGCAGTAACCTCAGC \\
NF $\kappa$ B & NF $\kappa$ B & GGGACTTCC \\
PR & Progesterone receptor & GGGACATGGTTTCT \\
SRE & MAPK/ERK & GGATGTCCATATTAGGA \\
STAT3 & STAT3 & GTCGACATTTCCCGTAAATCGTCGA \\
\hline
\end{tabular}

cells using Lipofectamine 2000 (Invitrogen), and cells were treated with or without recombinant mouse Klotho in OPC culture medium as described above. Twenty-four hours after transfection, cells were washed once with PBS and assayed for luciferase activity using the Dualluciferase system (Promega) as described previously (Oh et al., 2010).
Immunofluorescence. Cells were fixed in 4\% paraformaldehyde in PBS at room temperature, rinsed with PBS, and treated for $1 \mathrm{~h}$ with blocking solution (PBS supplemented with $0.1 \%$ Triton X-100 and 1\% BSA). Cells were incubated overnight at $4^{\circ} \mathrm{C}$ with the primary antibody diluted in blocking solution. Cells were stained with antibodies to Olig2 (1:10,000; Millipore), CC-1 (1:200; Millipore), or O1 (1:2; ATCC). Subsequently, cells were rinsed and incubated with the relevant secondary antibodies (Cy3 or Alexa-488; Jackson ImmunoResearch Laboratories) for $1 \mathrm{~h}$ at room temperature. Immunofluorescence images were obtained by a Nikon Eclipse 660 microscope and a SPOT-cooled CCD digital camera (Diagnostic Instruments). For every condition, we identified the maturation state of each OL for the $\sim 30-60$ cells within a given field for all fields acquired ( $N=450-900$ cells/condition) from 3 independent experiments. We quantified numbers of mature $\mathrm{OLs}\left(\mathrm{O}^{+}{ }^{+}\right.$or $\left.\mathrm{CC}^{+}\right)$and total OL-lineage cells $\left(\mathrm{Olig} 2^{+}\right)$and determined percentage mature OLs of total $\mathrm{OL}^{-}$lineage cells $\left(\mathrm{O}^{+} / \mathrm{Olig} 2^{+}\right.$or $\left.\mathrm{CC}^{+} / \mathrm{Olig} 2^{+}\right)$(because Olig2 labels OPCs as well as OLs).

Cell number determination, cell viability assay, and $\mathrm{LDH}$ release. Cell number was determined colorimetrically by crystal violet staining as described previously (Zeldich et al., 2007). Cells were plated at 50,000 cells/ well in 24-well plates in triplicates and allowed to attach and spread in OPC culture medium containing bFGF/PDGF for $1-3 \mathrm{~d}$ and then replaced with medium containing CNTF and NT3, with or without Klotho for the indicated time periods. At the end of each time interval, the cells were washed with PBS, fixed in $70 \%$ ethanol, and kept at $4^{\circ} \mathrm{C}$ until the staining with $1 \%$ crystal violet. Unincorporated stain was removed by washing, cells were air-dried, and the dye was extracted with $70 \%$ ethanol and optical density (absorbance $550 \mathrm{~nm}$ and baseline reference absorbance $750 \mathrm{~nm}$ ) was measured by Microplate Reader (Glomax Multi Detection System, Promega). The data analysis was done by subtracting the baseline readings $(750 \mathrm{~nm})$ from the absorbance readings $(560 \mathrm{~nm})$.

For cell viability assay, cells were plated in 96-well plates in six repeats and allowed to attach and spread in OPC culture medium containing bFGF/PDGF for $3 \mathrm{~d}$ and then replaced with medium containing CNTF and NT3, with or without Klotho for the indicated time periods. At the end of each time interval, cell number was assessed using CellTiter-Glo Luminescent Cell Viability Assay (Promega) according to the manufacturer's instructions. This assay signals the presence of metabolically active cells. Briefly, $100 \mu \mathrm{l}$ of CellTiter Glo Reagent was added to the equal volume of cell culture medium present in each cell culture well. The contents were mixed for $2 \mathrm{~min}$ and after stabilization of the signal at room temperature for $10 \mathrm{~min}$, the luminescence was recorded on a Microplate Reader (Glomax Multi Detection System, Promega). Cell death was assessed by using the CytoTox 96 nonradioactive cytotoxicity assay (Promega), which measures the LDH release into the medium.

Immunohistochemistry and cell counting in wild-type and Klotho knockout mice. Five-week-old Klotho ${ }^{+/+}$and Klotho ${ }^{-1-}$ mice were perfused through the heart with $0.1 \mathrm{M}$ PBS $\left(4^{\circ} \mathrm{C}, \mathrm{pH} 7.4\right)$. The brains were removed, and one hemisphere was immersion fixed in $4 \%$ paraformaldehyde overnight while the other was left unfixed and flash frozen with pulverized dry ice and stored at $-80^{\circ} \mathrm{C}$. The fixed hemisphere was removed from fixative the next day and cryoprotected in successive solutions of first $10 \%$, then $20 \%$ glycerol in PBS with $2 \%$ DMSO (Rosene et al., 1986). The frozen hemibrains were cut in the coronal plane into $30-\mu \mathrm{m}$-thick sections with a sliding microtome. The sections were divided into six interrupted series and stored at $4^{\circ} \mathrm{C}$ in $0.1 \mathrm{M}$ PBS with $1 \%$ sodium azide as a preservative until they were processed.

For Olig2, CC-1, and GST-Pi immunohistochemistry, one series from each subject was selected and all sections were processed together in a single batch at the same time in the same reagents to eliminate any procedural variance. All steps were performed at room temperature unless otherwise indicated. Free-floating sections were washed, quenched with $3 \%$ hydrogen peroxide, and then blocked with $10 \%$ normal goat serum in PBS with $0.4 \%$ Triton X-100 for $1 \mathrm{~h}$. Next, sections were incubated in a stock solution ( $1 \%$ normal goat serum, $0.2 \%$ Triton X-100 in $0.05 \mathrm{M}$ PBS) containing rabbit polyclonal anti-Olig2 antibody (Millipore ab9610, 1:10,000), mouse mAb against CC-1 (Millipore OP-80, 1:40) or anti-GST Pi (Abcam, 1:500) for $48 \mathrm{~h}$ at $4^{\circ} \mathrm{C}$. Sections were then washed in 
stock solution and treated with biotinylated goat anti-rabbit or anti-mouse secondary antibody (1:600, BA5000, Vector Laboratories) for $1 \mathrm{~h}$. After washing, sections were incubated with an avidin-biotinylated horseradish peroxidase enzyme complex (PK6100, Vectastain Elite $\mathrm{ABC}$ kit, Vector Laboratories) for $1 \mathrm{~h}$, rinsed in KPBS, then sodium acetate buffer $(0.175 \mathrm{M})$, and processed with a solution of nickel sulfate hexahydrate $(0.095 \mathrm{M}), 3,3 \mathrm{di}-$ aminobenzidine tetrahydrochloride (DAB) $(0.55 \mathrm{~mm})$, and hydrogen peroxide $(0.0025 \%)$ in $0.175 \mathrm{~m}$ sodium acetate buffer for $15 \mathrm{~min}$. The immunostained sections were mounted on gelatin-coated slides and air-dried. Then sections were defatted in chloroform:ethanol (1:1), rehydrated, counterstained with Neutral Red (1\%), dehydrated in a series of ethanols, cleared in xylenes, and coverslipped with Permount (Fisher Scientific).

To quantify Olig2 ${ }^{+}$and GST-Pi ${ }^{+}$cells, the fractionator method was used to obtain a population estimate within the fimbria. The fimbria was chosen because it is an easily defined and circumscribed bundle of white matter. The fimbria was outlined in six $30 \mu \mathrm{m}$ sections spaced $180 \mu \mathrm{m}$ apart, starting rostrally at the level of the anterior end of the habenula and spanning $\sim 1.08 \mathrm{~mm}$ caudally using StereoInvestigator system (Version 9.14.3, MBF Bioscience) and a $4 \times$ Nikon Plan objective on a Nikon Eclipse E600 microscope. Cell counts were made with a $20 \times$ Nikon Plan Fluor objective. A $120 \mu \mathrm{m} \times 120 \mu \mathrm{m}$ grid was overlaid on the region of interest, and Olig ${ }^{+}$cells were counted within $40 \mu \mathrm{m} \times 40 \mu \mathrm{m}$ counting frames placed at the grid intersections that fell within the outline of the fimbria. The criterion for counting cells was the appearance of the black Ni-DAB immunoproduct in the nucleus. In an adjacent series of six 30- $\mu \mathrm{m}$-thick tissue sections, GST-Pi ${ }^{+}$cells within the fimbria were quantified. The fimbria was outlined with a $4 \times$ objective as described above. A $120 \mu \mathrm{m} \times 120 \mu \mathrm{m}$ sampling grid was superimposed over the region of interest, and GST-Pi ${ }^{+}$cells were counted within a $40 \mu \mathrm{m} \times 40$ $\mu \mathrm{m}$ counting frame and $5 \mu \mathrm{m}$ disector using a $60 \times$ Nikon Plan Fluor oil objective. A guard volume of $1 \mu \mathrm{m}$ above the disector box was used and 2-4 $\mu \mathrm{m}$ below, depending on the thickness of the tissue section $(\sim 8-10$ $\mu \mathrm{m}$ total). GST-Pi ${ }^{+}$cells had brown DAB immunoproduct in the cytoplasm and nucleolus, yet the nucleus was unstained.

Nodal and paranodal immunofluorescence. Free-floating $30 \mu \mathrm{m} \mathrm{sec-}$ tions were stained for nodes and paranodes with rabbit anti- $\beta$-IV spectrin (1:400) or rabbit anti-Na 1.6 (1:200) (gifts from M. Rasband, Baylor College of Medicine) (Rasband et al., 2003; Ogawa et al., 2006), and mouse anti-caspr antibodies (1:500), using the following protocol with all steps performed at room temperature unless otherwise stated. The monoclonal antibody mouse anti-caspr (clone K65/35) was developed by and obtained from the UC Davis/National Institutes of Health Neuromab Facility. Sections were washed in PBS, transferred to prewarmed 10 mu sodium citrate, $\mathrm{pH} 8.5$, and incubated at $80^{\circ} \mathrm{C}$ for $30 \mathrm{~min}$ for antigen retrieval. After cooling to room temperature, sections were washed 3 times in PBS, then blocked and permeabilized in PBS with $0.3 \%$ TX-100 (Sigma) and 10\% normal donkey serum (Jackson ImmunoResearch Laboratories) for $30 \mathrm{~min}$. Sections were then placed directly in MOM Block (Vector Laboratories) diluted in PBS for $1 \mathrm{~h}$, washed 3 times in PBS, and then incubated overnight in primary antibody cocktails. The next day, after 3 washes in PBS, sections were incubated in donkey anti-mouse Cy2 (Jackson ImmunoResearch Laboratories; 1:300) and donkey anti-rabbit DyLight 549 (Jackson ImmunoResearch Laboratories; 1:300) for $1 \mathrm{~h}$. Sections were then mounted on gelatin subbed slides, air dried, and dehydrated with $70-100 \%$ EtOH and xylene and coverslipped with DPX mounting medium.

Image acquisition was performed on a Nikon Eclipse $\mathrm{Ti} \mathrm{C} 2{ }^{+}$laser scanning confocal microscope. Two-micron optical sections at $100 \times$ optical objective with $2 \times$ digital zoom were obtained from five different immunolabeled sections from each of two wild-type and two Klotho-null mice. The imaged white matter included corpus callosum overlying striatum to that overlying hippocampus. Maximum intensity projections were obtained and images were postprocessed in NIS Elements software (Nikon). Nodal and paranodal segments were measured using the twopoint length measurement tool. For measurement, only complete paranodal pairs (both paranodes and an immunolabeled node) were selected for measurement. A total of 30 paranodes per section (150 per animal) were measured, and a total of 10 nodes per section ( 50 per animal) were measured. Statistical significance was determined using a Student's $t$ test assuming one tail and equal variance. For presentation, images were further postprocessed and cropped in Photoshop CS5 (Adobe).

Electron microscopy. Thirty-five-day-old Klotho ${ }^{+/+}$, Klotho $^{+/-}$, and Klotho $^{-1-}$ mice, and 25-d-old Klotho ${ }^{-1-}$ mice were perfused transcardially with $1 \%$ paraformaldehyde and $2.5 \%$ glutaraldehyde fixative in 0.1 M cacodylate buffer, pH 7.2-7.4. Optic nerve, corpus callosum, and cervical spinal cord were postfixed with $1 \%$ osmium oxide, dehydrated in alcohol series and propylene oxide before embedding in Epon. Onemicrometer-thick sections were cut and stained with toluidine blue. Thin sections were contrasted with uranyl acetate and lead citrate and imaged with a JEOL 1200EX electron microscope.

Gene set enrichment analysis. Gene set enrichment analysis was performed according to Subramanian et al. (2005) with 1186 chemical and genetic perturbation gene sets. Klotho ${ }^{-1-}$ mice versus Wild-type ${ }^{+/+}$ mice gene expression profiles were ranked based on $p$ value. The ranked gene list was used as input for the chemical and genetic perturbation gene sets. The significant gene sets were selected based on the normalized enrichment score and false discovery rate, accordingly.

\section{Results}

\section{Klotho effects on primary oligodendrocytes in vitro}

Klotho has been reported to affect intracellular signaling through Akt and ERK1/2 pathways in HEK293 and breast cancer cells (Kurosu et al., 2006; Wolf et al., 2008). We therefore assessed whether Klotho induces ERK1/2 and Akt protein phosphorylation from 0-60 min in OPCs isolated from rat brain. Western blot results indicated that proteins in the ERK1/2 and Akt pathway, including PTEN (Ser380), Akt (Ser473), and GSK-3 $\beta$ (Ser9), were phosphorylated upon Klotho treatment (Fig. 1). We found two waves of GSK3 $\beta$ phosphorylation in OPCs upon Klotho treatment, with a first peak at $10 \mathrm{~min}$ and a second at $45 \mathrm{~min}$ (Fig. 1). These results suggest that the Akt and ERK/12 pathways are both involved in Klotho-induced signaling in rat primary OPCs. We also examined phosphorylation of FGF receptor substrate 2 (FRS2) because Klotho may function by modulating FGF signal transduction pathways 
A

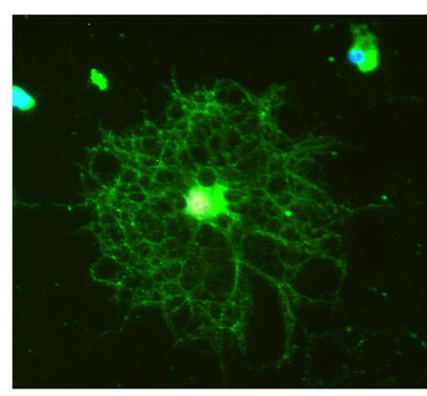

B

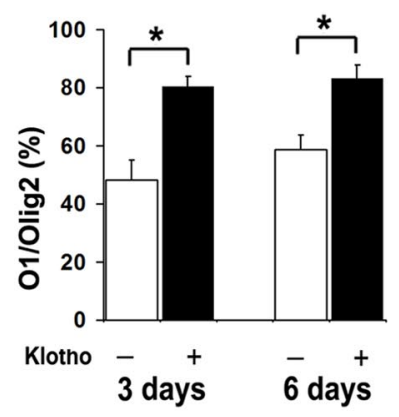

C

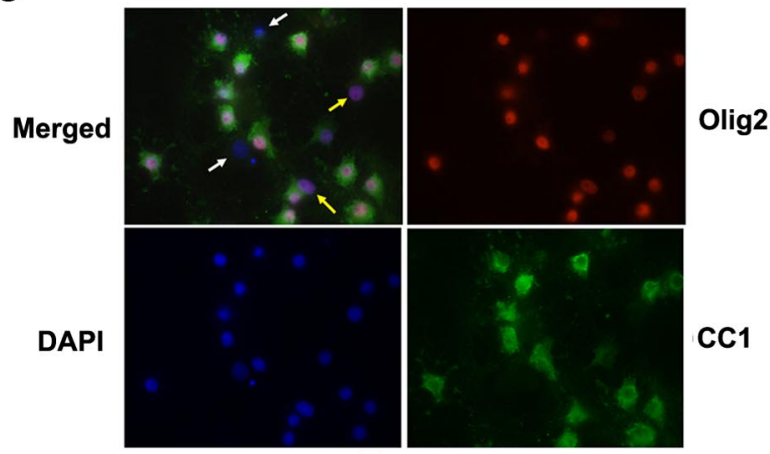

D

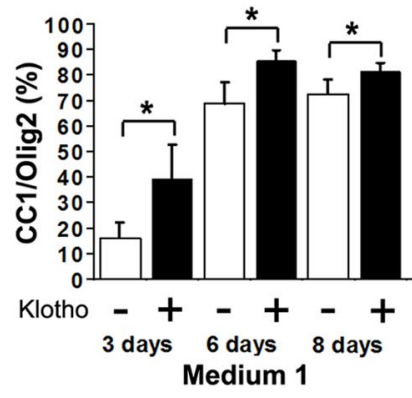

$\stackrel{+}{*} \quad \mathbf{E}$

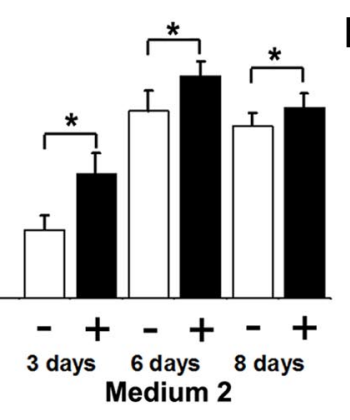

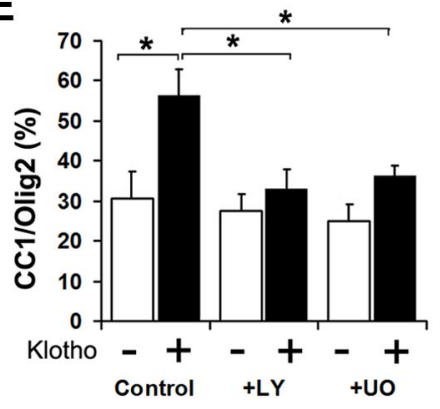

F

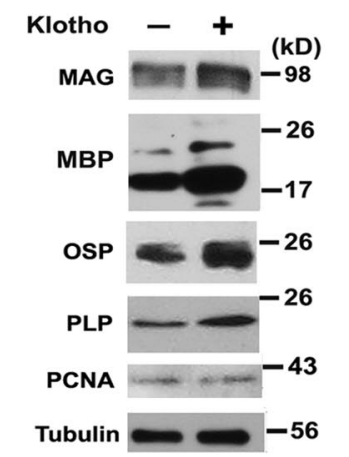

$\mathrm{H}_{\text {\% }}$
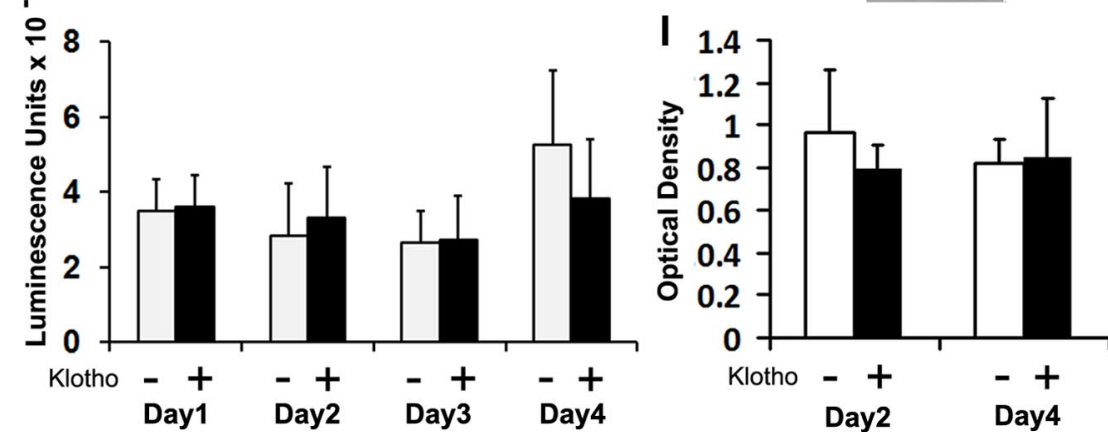

Figure 2. Klotho effects in vitro on primary OPCs. A-D, Klotho enhances oligodendrocyte maturation. Rat OPCs were treated with Klotho (+ Klotho) or with PBS (Control) for $3 \mathrm{~d}$, and then immunostained for the mature oligodendrocyte marker 01 (green), and pan-oligodendrocyte marker 0lig2 (red). $\boldsymbol{A}$, A typical 01 staining of a differentiated oligodendrocyte. $\boldsymbol{B}$, Statistical analysis of 01 and 0 lig2 staining of OPCs at 3 and 6 d treatment with Klotho or PBS. *Statistical significance ( $p<0.005, t$ test). Error bars indicate SD. $C$, Immunostaining of 0 PCs with antibodies to the mature oligodendrocyte marker CC-1 (green) and pan-oligodendrocyte marker Olig2 (red). Cell nuclei were stained with DAPI (blue). White arrows in the merged image indicate nonoligodendrocytic cells, and yellow arrows indicate undifferentiated oligodendrocytes. D, Statistical analysis of the ratio of CC -1 to 0 lig2 staining of OPCs at 3, 6, and $8 \mathrm{~d}$ of treatment with Klotho or PBS in medium 1 (OPC culture medium containing (NTF and T3) or medium 2 (OPC culture medium containing CNTF, T3, and NT3). * Statistical significance ( $p<0.005, t$ test). Error bars indicate SD. E, Klotho enhances OPC maturation via ERK and Akt signaling. Rat OPCs were treated with $0.5 \mu \mathrm{m}$ LY294002 (LY) (for Akt inhibition) or $1 \mu \mathrm{m}$ U0126 (U0) (for ERK inhibition) for 30 min before Klotho (KL) was added. OPCs were treated for $3 \mathrm{~d}$ and then immunostained as in $\boldsymbol{D}$. Statistical analysis of the results is plotted. $\boldsymbol{F}$, Klotho enhances major myelin proteins expression in rat $0 P(s$. OPCs were treated with or without Klotho for $6 \mathrm{~d}$ in culture medium containing CNTF and T3 and blotted with the antibodies indicated with tubulin as loading control. $\mathbf{G}$, The relative signal intensity based on band densitometry was plotted as relative percentage to control without Klotho treatment. Results represent the average of three to five independent experiments. All proteins are normalized to tubulin internal control. *Statistical significance ( $p<0.005, t$ test). Error bars indicate SD. $\boldsymbol{H}$, Klotho does not affect OPC cell viability. CellTiterGlo assay was used to assess Klotho's effect on OPC cell viability after $1-4 \mathrm{~d}$ of Klotho treatment. Error bars indicate SD. Results represent the average of six independent experiments. I, Klotho does not affect OPC cell proliferation. Cell numbers were assayed by crystal violet staining at day 2 and day 4 after Klotho treatment. Error bars indicate SD. Results represent the average of three independent experiments.

(Kurosu et al., 2006; Urakawa et al., 2006). Western blot results indicated that FRS2 was phosphorylated at Y196 upon Klotho treatment (Fig. 1), suggesting that the FGF signaling pathways may be involved in Klotho-induced signaling in rat OPCs. However, it is also possible that Klotho affects FRS2 phosphorylation via Klotho's interaction with the TrkA receptor (Meakin et al., 1999).

To examine the effects of Klotho on the OPC phenotype, oligodendrocyte maturation was assessed by immunohistochemistry for mature oligodendrocytes (O1), and pan-oligodendrocytes (Olig2) after Klotho treatment. The OPCs were allowed to attach and spread in OPC culture medium containing bFGF/PDGF for
$3 \mathrm{~d}$ and then replaced with medium containing CNTF and NT3 with or without Klotho. After 3 and 6 d of Klotho treatment, we found that Klotho increased the percentage of mature primary oligodendrocytes (\% O1/Olig2; Fig. 2A,B). Similar results were obtained using another marker of mature oligodendrocytes, CC-1 (Fig. 2C). Klotho enhances OPC maturation in medium containing CNTF and T3, or in medium containing CNTF, T3, and NT3 (Fig. 2D). Because both Akt and ERK1/2 phosphorylation occurred rapidly after exposure to Klotho, we asked whether Akt and ERK1/2 function is required for Klotho's effects on OPC maturation. OPCs were treated with Klotho in the presence or absence of Akt and ERK inhibitors (LY294002 (LY) for Akt inhi- 
bition or UO126 (UO) for ERK inhibition). Inhibition of ERK function reduced, while Akt functional inhibition completely abolished, the effects of Klotho on OPC maturation (Fig. 2E), suggesting that Klotho enhances OPC maturation primarily via signaling requiring Akt but also, to a more limited degree, through ERK1/2. Western blot analysis of Klotho-treated OPCs revealed that Klotho enhanced the expression of the major myelin proteins, including MAG, MBP, oligodendrocyte-specific protein (OSP/Claudin11), and PLP (Fig. 2F,G), confirming that Klotho enhances OPC maturation in vitro. Western blotting for the cell proliferation marker, PCNA, revealed no difference with Klotho treatment (Fig. 2F,G), suggesting that Klotho does not enhance OPC proliferation. We also examined cell number and cell viability by crystal violet staining and CellTiterGlo assay, which reflects the amount of the ATP present, and we found no difference in Klotho-treated and untreated OPCs from day 1 to day 4 in the cell viability assay and for day 2 and day 4 for crystal violet staining (Fig. $2 \mathrm{H}, \mathrm{I}$ ). Because OPCs were allowed to attach and spread for $3 \mathrm{~d}$ in the presence of basic FGF (bFGF) and PDGF, cell proliferation occurred during this period. After we treated the OPCs with Klotho in culture medium containing CNTF and T3, OPCs started to differentiate but cell numbers remained constant as shown in Figure $2 H, I$. We also observed no difference with a cell death assay by measuring LDH release to the media with or without Klotho. These results suggest that Klotho affects oligodendrocyte differentiation and maturation, but not their proliferation and cell death.

\section{qRT-PCR analysis of Klotho effect on OPC maturation}

Recently a transcriptome database for astrocytes, neurons, and oligodendrocytes has been published providing cell type-specific markers for these neural cells (Cahoy et al., 2008). To confirm the effect of Klotho on OPC maturation, we performed qRT-PCR analysis of the top 45 genes (see Table 4 for primers information) from the OL maturation enriched gene list (Cahoy et al., 2008) using RNA isolated from OPCs treated with Klotho or PBS only, for 3 or $7 \mathrm{~d}$. qRT-PCR revealed that, comparing 3 and $7 \mathrm{~d}$ differentiated OPC, most of the genes were highly expressed at day 7 but had either low or undetectable expression at day 3 (Fig. 3A), suggesting that the primer sets were working well to detect OPC maturation-enriched genes. We then analyzed the gene expression changes of RNA from OPC treated with Klotho for $7 \mathrm{~d}$ compared with PBS-treated control. We found that 37 of the 45 genes were detectable, and 78\% (29 of 37) of the genes were upregulated by Klotho. Of those 37, 21 genes reached significance of $p<0.05$ (Fig. 3B). The qPCR results were consistent with the results obtained from protein expression as assessed by Western blot in that the expression of major myelin proteins was enhanced 2- to 3-fold in response to exogenous addition of Klotho (Fig. $2 F, G$ ). These results demonstrate that Klotho can enhance
3 days

7 days

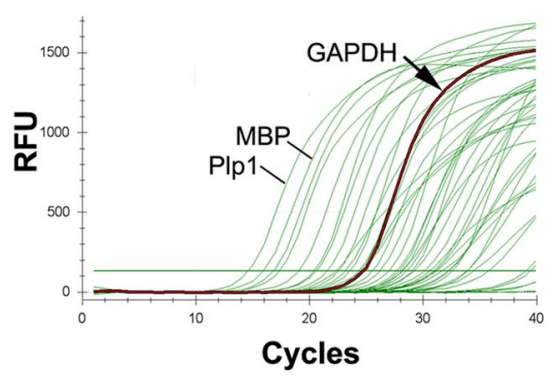

Cycles

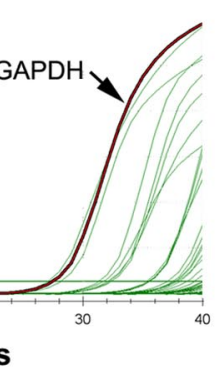

Cycles

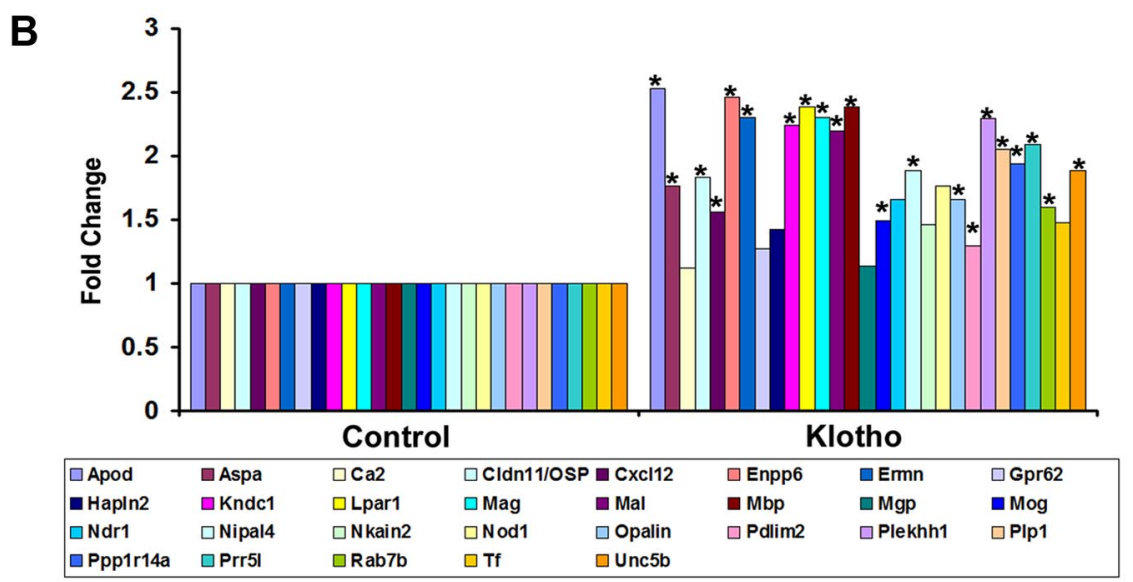

Figure 3. qRT-PCR confirmation of the effect of Klotho on OPC maturation. $A$, Representative qPCR results of differentiated OPCS d. The housekeeping gene GAPDH and the top two expressed genes, MBP and PIp1, are indicated. $\boldsymbol{B}$, Fold change results ( in medium containing bFGF and PDGF for $3 \mathrm{~d}$, and then changed to the differentiation medium with CNTF and $\mathrm{T} 3$ with or without Klotho for $7 \mathrm{~d}$. ${ }^{*}$ Statistical significance $(p<0.05, t$ test).

OPC maturation as shown by the immunostaining of the cells with two separate oligodendrocyte markers $\mathrm{O} 1$ and $\mathrm{CC}-1$, and by Western blot analyses as shown in Figure 2B, $D, F, G$.

\section{Effects of Klotho absence in vivo in Klotho knock-out mice}

If Klotho is important for oligodendrocyte maturation in vitro, Klotho knock-out mice should exhibit deficiencies in myelination. The ultrastructure of 35-day-old Klotho knock-out $(-/-)$, hemizygous $(+/-)$ and control $(+/+)$ mice brains was examined by electron microscopy. There was a significant reduction in the percentage of myelinated fibers in both optic nerve and corpus callosum, but not cervical spinal cord (Fig. 4), suggestive of region-specific effects of Klotho expression. In the optic nerve, Klotho $^{-1-}$ mice exhibited a drastic reduction in the percentage of myelinated fibers ( $10 \%$ compared with $90 \%$ in $+/+$ littermates) (Fig. 4E, F,M), whereas Klotho ${ }^{+/-}$mice showed normal numbers of myelinated fibers (Fig. 5C,D compared with Fig. $5 A, B)$. In the corpus callosum, both Klotho ${ }^{+/-}$and Klotho ${ }^{-1-}$ exhibited significantly impaired myelination (20\% compared with $90 \%$ in $+/+$ mice) (Fig. $4 G-M$ ). No significant change was seen in the percentage of myelinated fibers in the spinal cord (Fig. $4 M)$. A similar reduction in the myelination of fibers in the corpus callosum was found in two 25 -d-old Klotho knock-out brains, with only $16.4 \pm 1.6 \%$ fibers being myelinated.

To decipher the potential basis for region-specific effects of Klotho, we examined the distribution of Klotho in the corpus callosum, spinal cord, and optic nerve from five 1.1-month-old and five 1.6-month-old mice. The results showed that Klotho was expressed in all three regions, with the highest expression in the corpus callosum and lowest in spinal cord at the younger age (1.1 


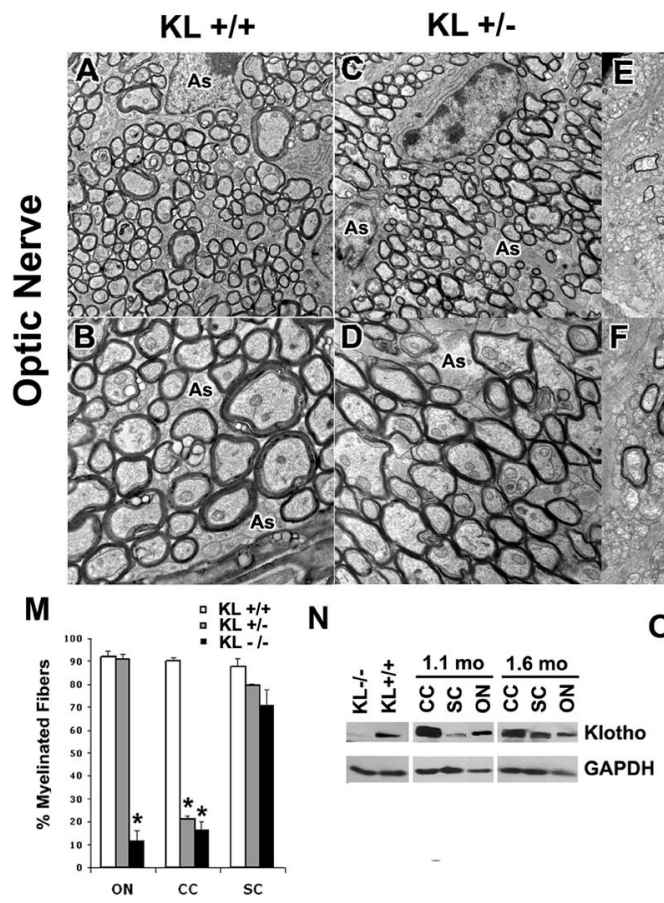

$\mathrm{KL}-/-$

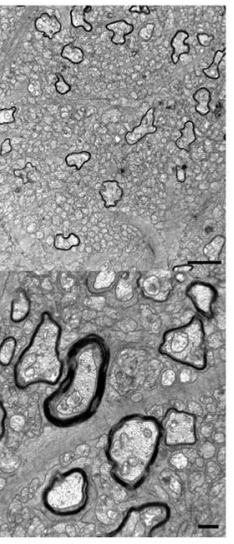

0

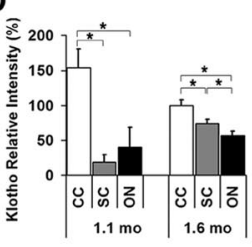

$\mathrm{KL}+/+$

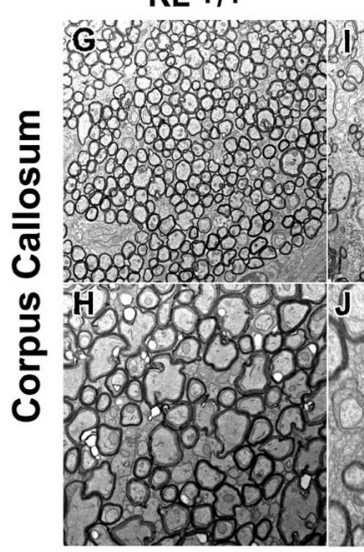

$\mathbf{P}$

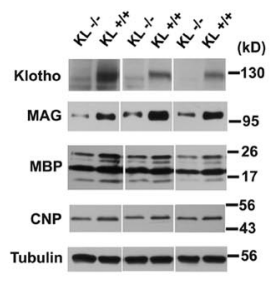

$\mathrm{KL}+/$ $\mathrm{KL}-/-$

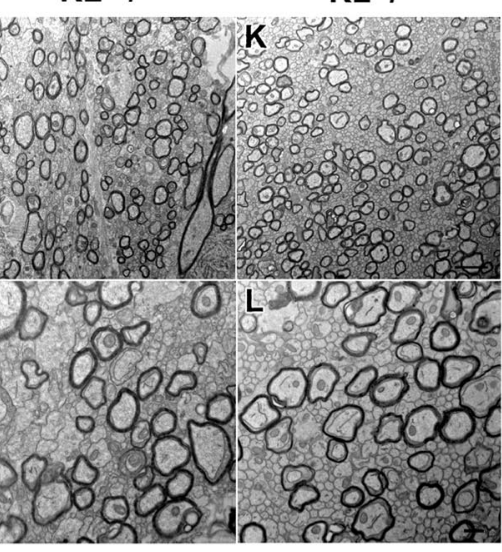

$\mathbf{Q}$

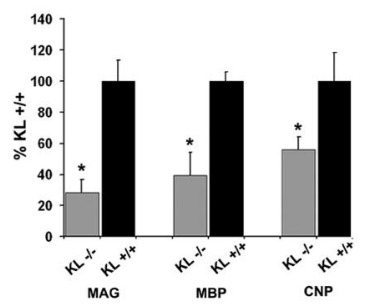

Figure 4. Klotho knock-out mice exhibit impaired myelination. $\boldsymbol{A}-\boldsymbol{L}$, The 4.5 -week-old Klotho ${ }^{+/+}$, Klotho ${ }^{+/-}$, or Klotho ${ }^{-/-}$mice were processed for electron microscopy. Cross-sectional images show examples of myelination patterns for optic nerve $(\boldsymbol{A}-\boldsymbol{F})$ at $2900 \times(\boldsymbol{A}, \boldsymbol{C}, \boldsymbol{E})$ and $5800 \times(\boldsymbol{B}, \boldsymbol{D}, \boldsymbol{F})$ and corpus callosum $(\boldsymbol{G}-\boldsymbol{L})$ at $2900 \times(\boldsymbol{G}, \boldsymbol{I}, \boldsymbol{K})$ and $5800 \times(\boldsymbol{H}, \boldsymbol{J}, \boldsymbol{L})$. Scale bars: $\boldsymbol{E}, 2 \boldsymbol{\mu}$ m; $\boldsymbol{F}, 500 \mathrm{~nm}$. As, Astrocyte. $\boldsymbol{M}$, The number of myelinated and unmyelinated axons were counted and graphed as percentage of myelinated fibers. Averages represent axonal counts analyzed from 3 to 6 different images. *Statistical significance ( $p<0.0001, t$ test). Error bars indicate SD. ON, Optic nerve; CC, corpus callosum; SC, spinal cord. $N$, Klotho expression in CC, SC, and ON. Western blot analysis of Klotho from the lysates of 1.1- and 1.6-month-old control mice CC, SC, and ON tissues. $\mathbf{0}$, Statistical analysis of Klotho expression in $\boldsymbol{N}$ with GAPDH as loading control. *Statistical significance ( $p<0.05, t$ test). Error bars indicate SD. Sample size is $n=4$ for each age. $\boldsymbol{P}$, Major myelin proteins were largely reduced in Klotho knock-out mice. Western blot analysis of myelin markers from the brain lysates of 8-week-old Klotho knock-out ( $\mathrm{KL}^{-/-}$) and control $\left(\mathrm{KL}^{+/+}\right)$mice. $\boldsymbol{Q}$, Statistical analysis of the myelin markers in $\boldsymbol{P}$ with tubulin as control. ${ }^{*}$ Statistical significance $(p<0.05, t$ test). Error bars indicate SD.

months, Fig. 4N,O). The results of the Western blots of the three specific brain samples represent the levels of available Klotho protein surrounding these three brain regions. A higher Klotho level (e.g., corpus callosum) implies that Klotho's function is needed in that region, and less Klotho suggests Klotho is less necessary (e.g., spinal cord). These data, together with the electron microscopy results, suggest that Klotho is required for proper myelination of fibers in the corpus callosum. We therefore examined the myelin markers MAG, MBP, and 2', $3^{\prime}$ cyclic nucleotide- $3^{\prime}$-phosphodiesterase in brain tissues of 8 -week-old Klotho knock-out and control mice. Western blot analyses demonstrated significant reduction of major myelin proteins in Klotho-deficient mice compared with control mice (Fig. 4P,Q), indicating that Klotho affects myelination via inducing myelin protein production by oligodendrocytes.

To assess the effects of the hypomyelination seen in Klotho $^{-1-}$ mice on axonal microdomain organization, freefloating sections were stained for caspr to label paranodes, and $\beta$-IV spectrin or $\mathrm{Na}_{\mathrm{V}} 1.6$ to label nodes. No differences were seen in nodal staining patterns between $\beta$-IV spectrin and $\mathrm{Na}_{\mathrm{V}} 1.6$ immunolabels. High-magnification confocal optical sections reveal that, within the corpus callosum, Klotho ${ }^{-1-}$ mice show a significant decrease in paranodal length compared with wild-type controls (Fig. 5). This decrease in paranodal length suggests that there is less robust myelination in each axon in the Klotho ${ }^{-1-}$ mice consistent with hypomyelination seen in the ultrastructural analysis. Although the absolute difference in paranodal length is small $(0.30 \mu \mathrm{m})$, this average value would translate to one less paranodal loop per axon (assuming each loop is $\sim 0.25 \mu \mathrm{m}$ ) (Trapp and Kidd, 2004). The decrease in paranodal length was associated with a corresponding significant increase in nodal length by $0.25 \mu \mathrm{m}$ (Fig. $5 E$ ). Analysis of nodal and paranodal domains in the corpus callosum (Fig. $5 F$ ) and optic nerve (data not shown) by electron microscopy did not demonstrate any ultrastructural changes in axonal microdomains. Because nodal length shortens during myelination (Dugandzija-Novakovic et al., 1995; Vabnick et al., 1996), this increase in nodal length likely represents more immature nodal segments in $\mathrm{Klotho}^{-1-}$ mice. Longer nodes may be more energetically unstable and lead to progressive axonal degeneration (Waxman, 1998).

Immunohistochemistry and quantitative analysis of brain sections from Klotho knock-out mice at 5 weeks of age showed a $\sim 30 \%$ reduction in the numbers of Olig $2^{+}$oligodendrocytelineage cells in the fimbria compared with control mice (Fig. $6 A-E)$. In the corpus callosum, we detected a similar trend toward a significant reduction in Olig ${ }^{+}$cells in Klotho knock-out mice (data not shown). In addition, we found a similar and confirmatory reduction $(21 \%)$ in the number of mature oligodendrocytes immunopositive for the GST-Pi marker (Mason et al., 2004), suggestive of reduced levels of GST-Pi-positive mature oligodendrocytes in the fimbria of Klotho-null mice compared with control mice (Fig. $6 F-J$ ).

To determine whether these changes in the expression of myelin proteins are also seen at the mRNA level, we performed microarray analysis using RNA from 8 -week-old Klotho ${ }^{+/+}$and Klotho $^{-1-}$ mice brain tissue, and applied gene set enrichment analysis to identify which canonical pathways were involved. With this approach, we found that a set of myelinrelated genes were downregulated. To examine whether Klotho affects gene expression of these myelin-related genes, we per- 
formed qRT-PCR analysis of the 15 myelin-related genes. The qRT-PCR results revealed that all of the myelin-related genes tested were reduced compared with control mice, and 11 of 15 genes were downregulated $>2$-fold (Table 1 ). The results demonstrate that lack of Klotho resulted in reduction in expression of major myelin genes.

To identify potential transcription factors involved in Klotho-mediated responses in OPCs, we examined regulatory effects of Klotho using a signaling pathway luciferase reporter system. We optimized transfection efficiency in primary oligodendrocytic cells by testing 15 available transfection reagents and found that Lipofectamine 2000 (Invitrogen) was superior for the luciferase reporter system in these cells (data not shown). We then tested 45 signaling pathway reporters (QIAGEN; Table 2) in OPCs with or without Klotho treatment. In addition, we also tested the Pax3 reporter because Pax3 repression is directly relevant to oligodendrocyte maturation to a myelinating phenotype (He et al., 2007). The results showed that Klotho inhibited C/EBP, $\mathrm{AP} 1, \mathrm{NF} \kappa \mathrm{B}$, and $\mathrm{Pax} 3$ activities, whereas it enhanced liver X receptor (LXR), antioxidant response element, STAT3, progesterone receptor, and SRE MAPK/ERK transcription factor activities (Fig. 7B; Table 3). The effect of Klotho on STAT3 phosphorylation in OPCs was also confirmed by Western blot (Fig. 7A). These results revealed the possible transcription factors involvement in Klotho-mediated responses in OPCs (Table 4).

\section{Discussion}

\section{Klotho affects oligodendrocyte} maturation and myelination

In prior work, our group discovered reductions in Klotho in the aging brain white matter (Duce et al., 2008), where myelin deficits are also observed (Hinman and Abraham, 2007), suggesting a connection between Klotho expression and myelination. Thus, in this manuscript, we focused on the effect of Klotho on oligodendrocytes, the myelinating cells of the CNS. Our findings indicate a dramatic and important effect of Klotho on oligodendrocyte maturation and on myelination. Klotho enhances expression of MBP, MAG, PLP, and OSP/claudin 11, all being major myelin proteins, and induces OPC maturation in vitro. In vivo, Klotho knock-out mice have severe hypomyelination of the optic nerve and corpus callosum, which alters axonal microdomain organization. Myelin defects associated with loss of Klotho expression strongly indicate that decreased Klotho expression could result in slowed action potential propagation, conduction block, and destabilized coordinated Scale bars, $500 \mathrm{~nm}$.
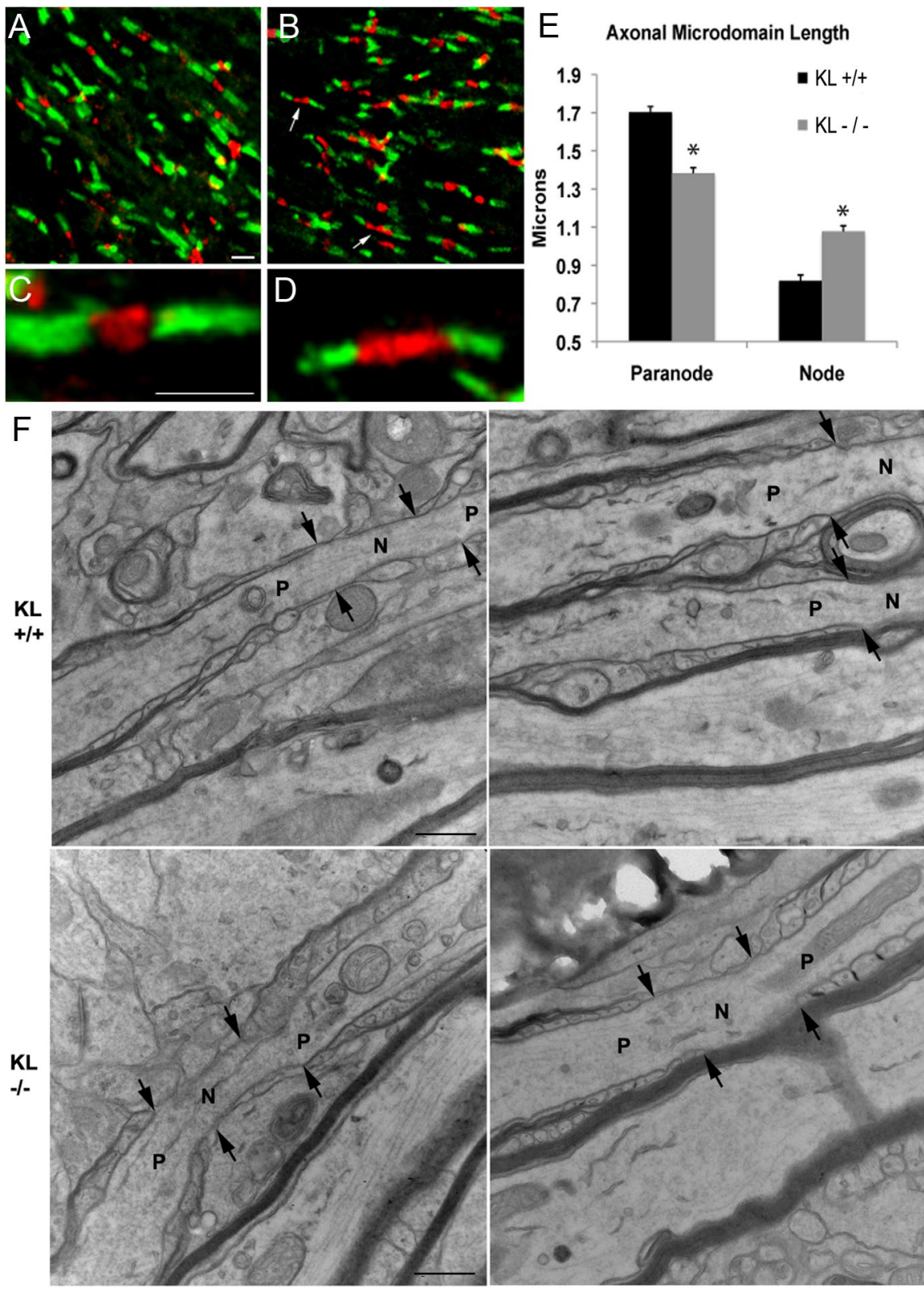

Figure 5. Axonal microdomains are altered in Klotho ${ }^{-1-}$ mice. Five sections each of corpus callosum from two wild-type and two homozygous Klotho ${ }^{-1-}$ mice were stained for caspr (green) and $\beta$-IV spectrin (red). $\boldsymbol{A}, \boldsymbol{C}$, Wild-type mice have normal compact paranodal and nodal structure. $\boldsymbol{B}, \boldsymbol{D}$, Klotho ${ }^{-1-}$ mice show an abundance of shorter paranodal segments and longer nodal segments (arrows). $\boldsymbol{E}$, Measurements of nodal and paranodal length show a statistically significant decrease in paranodal length in Klotho ${ }^{-1-}$ mice associated with a significant increase in nodal length. *Statistical significance ( $p<0.001, t$ test). Scale bar, $2 \mu \mathrm{m}$. $\boldsymbol{F}$, Electron microscopic longitudinal section analysis of nodes of Ranvier in corpus callosum from wild-type ( $\mathrm{KL}^{+/+}$) and $\mathrm{Klotho}^{-1-}\left(\mathrm{KL}^{-/-}\right)$mice at 13,000 $\times$. Arrows indicate the junction between node and paranode. N, Node; P: paranode.

neuronal communication, as seen in hypomyelinating and demyelinating diseases (Hinman and Abraham, 2007; Hanafy and Sloane, 2011). The numbers of myelinated fibers in the optic nerves and corpus callosum of the Klotho knock-out mice were much lower that in the wild-type mice, as determined by electron microscopy studies (Fig. 4). However, the numbers of mature and total oligodendrocytes in the fimbria were reduced by a lower percentage (Fig. 6). These data suggest that those oligodendrocytes that appear mature, as judged by their staining with GST-Pi, were not able to myelinate axons properly, indicating an important role of Klotho in the myelination process. 
$\mathrm{KL}+/+$
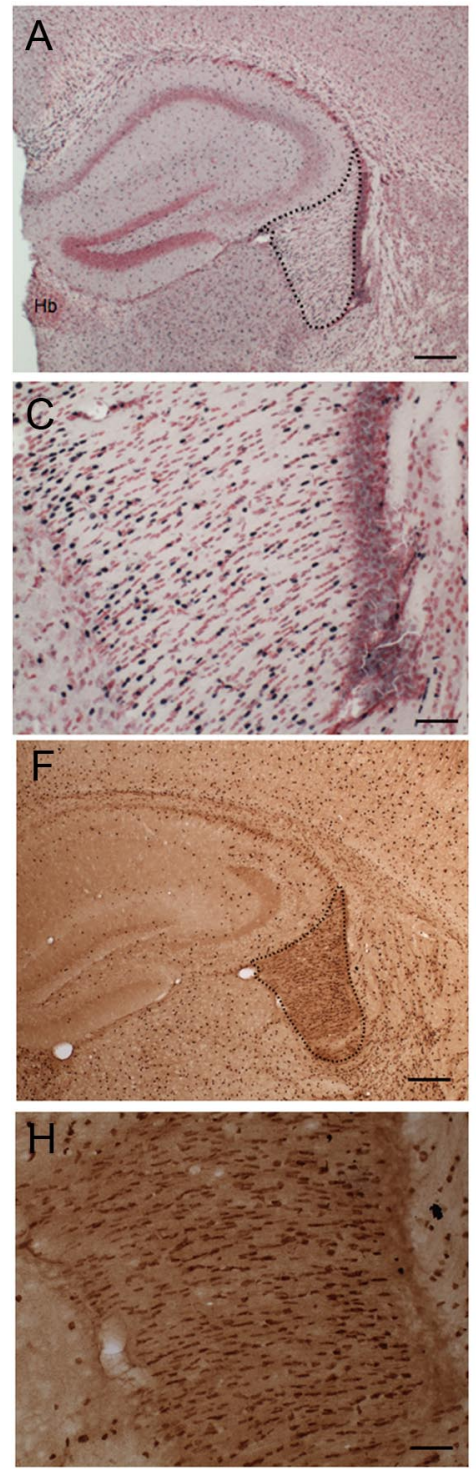

KL -/-
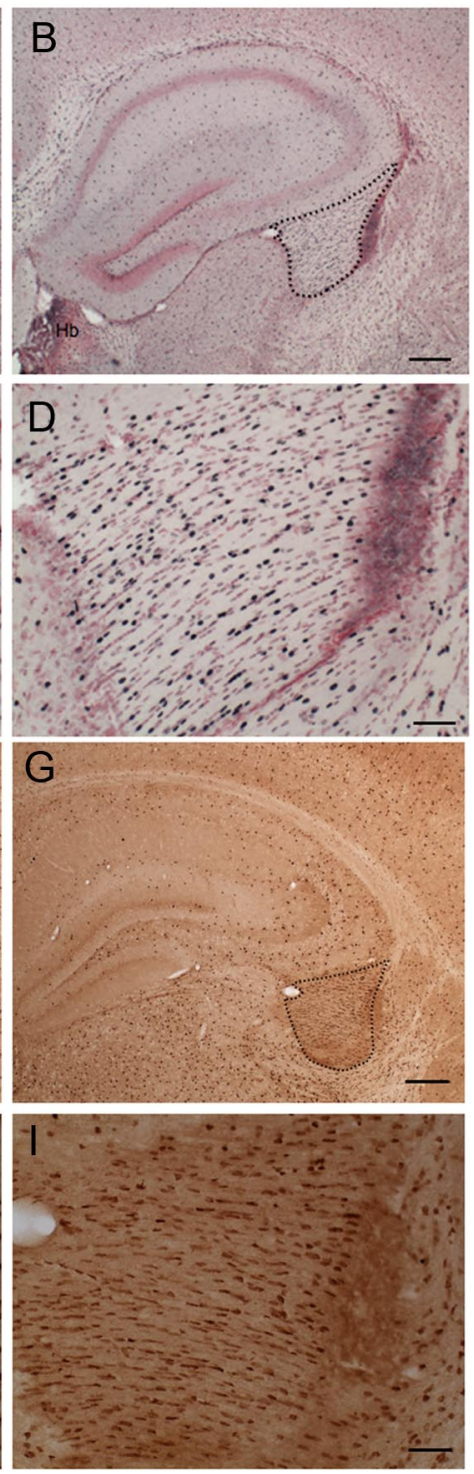

E

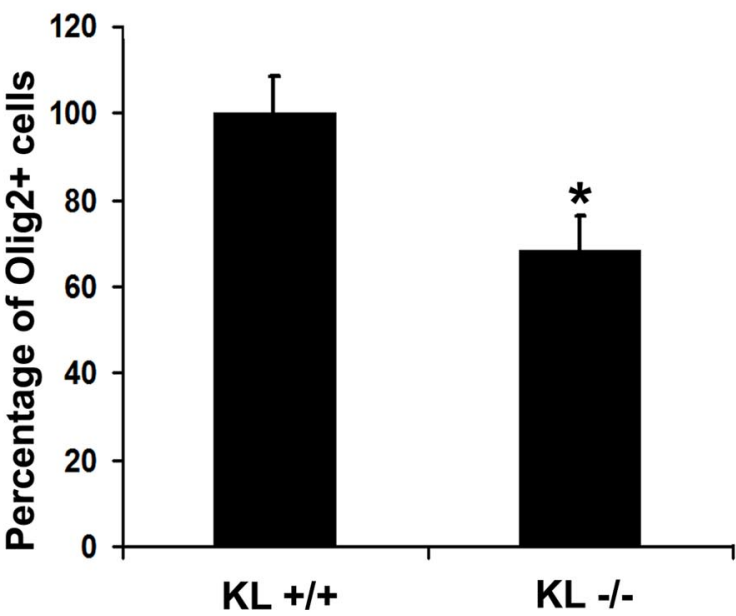

J

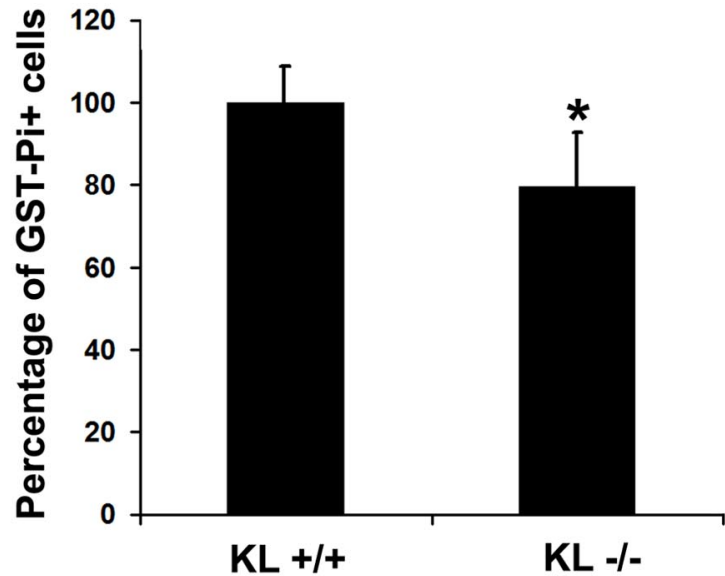

Figure 6. Immunohistochemistry and quantitative analysis of expression of Olig2 and GST-Pi in brain sections from 5 -week-old Klotho ${ }^{+/+}$and Klotho ${ }^{-/-}$mice. $A-D$, IHC images show examples of Olig2 nuclear staining patterns at $4 \times(\boldsymbol{A}, \boldsymbol{B})$ and $20 \times(\boldsymbol{C}, \boldsymbol{D})$. Scale bars: $\boldsymbol{A}, \boldsymbol{B}, 200 \mu \mathrm{m} ; \boldsymbol{C}, \boldsymbol{D}, 50 \mu \mathrm{m} . \boldsymbol{A}, \boldsymbol{C}, \mathrm{KL}^{+/+} . \boldsymbol{B}, \boldsymbol{D}, \mathrm{KL}^{-1-}$. The fimbria region is outlined. Hb, Habenula. $\boldsymbol{E}$, Cell counting of Olig2 ${ }^{+}$was performed as described in Materials and Methods. The number of Olig2 ${ }^{+}$cells in fimbria were counted and the percentage of 0 lig2 ${ }^{+}$cells in KL ${ }^{+/+}$and KL ${ }^{-1-}$ graphed. *Statistical significance $(p<0.01, t$ test). Error bars indicate SD. $\boldsymbol{F}-\boldsymbol{I}, \mathrm{IHC}$ of brain sections with antibodies to the mature oligodendrocyte marker GST-Pi at $4 \times(\boldsymbol{F}, \boldsymbol{G})$ and $20 \times(\boldsymbol{H}, \boldsymbol{I})$. Scale bars: $\boldsymbol{F}, \mathbf{G}, 200 \mu \mathrm{m} ; \boldsymbol{H}, \mathbf{I}, 50 \mu \mathrm{m}$. J, Quantitation of GST-Pi ${ }^{+}$cells as described in Materials and Methods. The GST-Pi ${ }^{+}$cells in fimbria were counted and the percentage of GST-Pi ${ }^{+}$cells in $\mathrm{KL}^{+/+}$and $\mathrm{KL}^{-1-}$ graphed. *Statistical significance $(p<0.05, t$ test). Error bars indicate SD.

Klotho-activated signaling pathways include Akt and ERK1/2 We found that Akt and ERK1/2 signaling likely regulates OPC cells subjected to Klotho treatment. This finding is consistent with the data reported by Wolf et al. (2008) who found that both pathways were involved in Klotho-treated HEK293 and breast cancer cells. Moreover, a recent study reported that Klotho induced ERK/MEK phosphorylation in HUVEC cells (Maekawa et al., 2011). Our results also suggest that Klotho could act on an as-yet unidentified Klotho receptor expressed on oligodendrocytes.

Oligodendrocyte development is regulated by numerous growth factors, which can signal through Akt- and ERK1/2dependent pathways (Bhat and Zhang, 1996; Baron et al., 2000; Bansal et al., 2003; Fortin et al., 2005; Du et al., 2006; Cui and Almazan, 2007; Frederick et al., 2007; Bibollet-Bahena et al.,
2009; Frost et al., 2009; Younes-Rapozo et al., 2009; Van't Veer et al., 2009; Fyffe-Maricich et al., 2011; Guardiola-Diaz et al., 2012). Klotho has been reported to regulate insulin/IGF-1, FGF23, and Wnt signaling (Kuro-o, 2006, 2008a). In OPCs, Klotho is unlikely to function through IGF-1 signaling because Klotho inhibits the insulin/IGF-1 signaling pathway (Kurosu et al., 2005) and IGF-1 was reported to enhance OPC maturation and myelination (Bibollet-Bahena and Almazan, 2009). It is unknown whether FGF23, for which Klotho serves as a coreceptor in the kidney, has a role in neurodevelopment. However, our findings show that Klotho treatment of OPCs induces the phosphorylation of FRS2, a positive regulator of FGF signaling upstream of Akt and Erk pathway, which is phosphorylated in oligodendrocytes upon activation of the FGF receptor (Bryant et al., 2009). Another putative receptor on OPCs is the NGF receptor TrkA because FRS2 is 
able to bind directly to both FGF and NGF receptors (Meakin et al., 1999; Ong et al., 2000). Possibly, Klotho functions through the FGF signaling pathway indirectly via another FGF ligand, or Klotho could modulate signaling of other cytokines in astrocytes via FGF signaling, as has been shown for insulin/IGF-1 signaling in Caenorhabditis elegans (Chateau et al., 2010). We cannot rule out the possibility that Klotho sequesters a ligand and blocks its accessibility to the receptor, or that Klotho binds directly to a receptor to prevent a ligand-receptor interaction. Another reported mechanism for Klotho effects is via the inhibition of the $\mathrm{Wnt} / \beta$ catenin pathway, where Klotho may function as a secreted Wnt antagonist (Liu et al., 2007). Activating the $\mathrm{Wnt} / \beta$-catenin pathway delays the development of myelinating oligodendrocytes (Fancy et al., 2009; Feigenson et al., 2009), whereas Olig2-induced neuronal stem cell differentiation into mature oligodendrocytes involves downregulation of the Wnt signaling pathway (Ahn et al., 2008). Whether Klotho stimulates oligodendrocyte maturation through the Wnt or insulin/IGF signaling pathways in addition to the FGF and NGF pathways is currently under investigation. It is interesting to note that, in vivo, FGFR1/2 and ERK1/2 MAPK signaling in oligodendrocytes has recently been shown to regulate the growth of the myelin sheath, independent of oligodendrocyte differentiation (Furusho et al., 2012; Ishii et al., 2012).

\section{Potential transcription factors involved in Klotho- mediated responses}

We identified a set of transcription factors potentially involved in Klotho-dependent effects on OPC cells using the luciferase reporter system. Several of the transcription factors have been reported previously to be associated with Klotho functions, including C/EBP, AP1/JNK, NF $\kappa \mathrm{B}$, STAT3, and SRE MAPK/ERK (Yamamoto et al., 2005; Chihara et al., 2006; Medici et al., 2008; Wolf et al., 2008; Hsieh et al., 2010; Thurston et al., 2010; Liu et al., 2011; Zhao et al., 2011). Klotho protein increases resistance to oxidative stress at the cellular and organismal level in mammals (Nagai et al., 2003; Kurosu et al., 2005; Rakugi et al., 2007; Shih and Yen, 2007). Klotho-deficient mice have impaired cognitive function compared with wild-type mice, and treatment with the antioxidant $\alpha$-tocopherol improves cognition (Nagai et al., 2003), suggesting that Klotho may function as a neuroprotective factor. In addition, Klotho protein showed a neuroprotective effect on human neural stem cells (Foster et al., 2011), likely through the antioxidative stress effect of Klotho. We found an increase in the antioxidant response element activity, which indicates that the antioxidative function of Klotho may be involved in the protection of oligodendrocytes. The new transcription factor activities identified to be associated with Klotho include Pax3, LXR, and the progesterone receptor. LXRs are oxysterol and nuclear receptors, which play an important role in the control of cholesterol homeostasis (Repa and Mangelsdorf, 2000; Whitney et al., 2002).

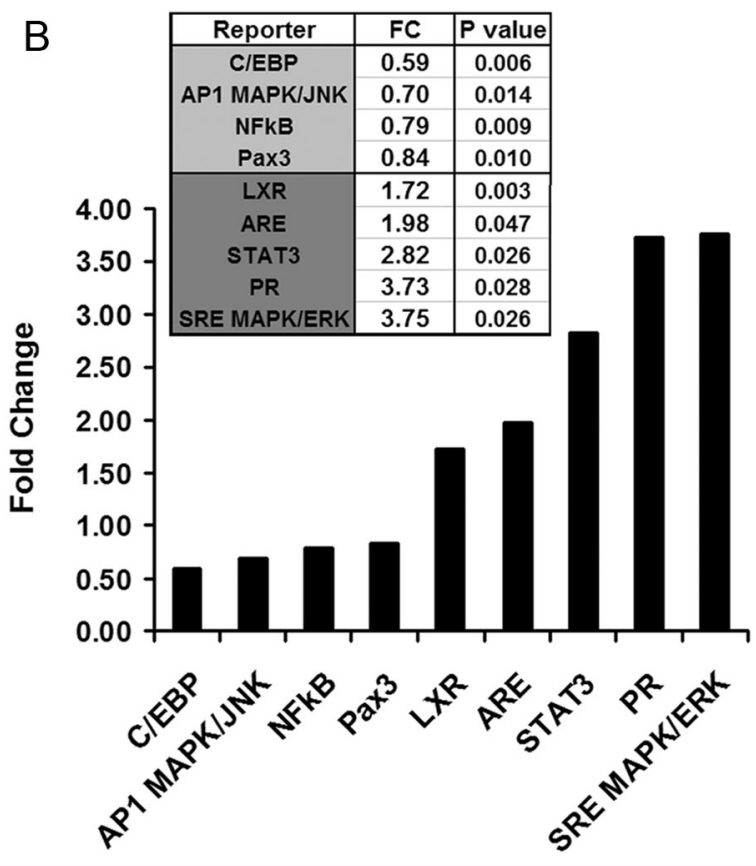

\section{for oligodendrocyte biology}

Implications of Klotho induced transcription factor changes

The lack of LXRs in mice leads to disorganized myelin sheaths, suggesting a role for the LXRs in myelination (Wang et al., 2002). Pax3 is important for development of myelinating glia and the myelination process (Wegner, 2000). An inverse correlation was observed between expression of Pax3 and MBP, suggesting that it represses MBP transcription (Kioussi et al., 1995). We found that Klotho inhibited Pax3 reporter activity and increased MBP expression in OPCs; therefore, we speculate that Klotho may increase MBP through the Pax3 pathway. Further investigation is required to decipher the direct or indirect involvement of the Pax3 transcription factor pathway resulting in Klotho's effects on oligodendrocytes. The transcription factor STAT3 has been previously reported to be involved in oligodendrocyte differentiation (Dell'Albani et al., 1998; Massa et al., 2000). Klotho treatment induced STAT3 phosphorylation, which is required for STAT3 activity (Bromberg and Darnell, 2000). Furthermore, the protein tyrosine phosphatase SHP-1 regulates oligodendrocyte differentiation through STAT3 in response to the IL- 6 family of cytokines (Massa et al., 2000). Thus, Klotho may also act through STAT3 to drive OPC maturation.

Regardless of which receptor, signaling pathway(s), and transcription factors are involved, our in vitro and in vivo studies indicate that Klotho clearly has a significant regulatory role in OPC maturation and developmental myelination. Interestingly, Klotho has been reported to have a role in cell differentiation of diverse systems throughout the body, including bone, fat, and the cardiovascular system (Kawaguchi et al., 1999; Shimada et al., 2004; Chihara et al., 2006). Klotho gene expression appears to cause the impairment of both osteoblast and osteoclast differentiation (Kawaguchi et al., 1999). In addition, both angiogenesis and vasculogenesis are impaired in Klotho mutant mice, suggesting a role for Klotho in differentiation of endothelial precursor cells (Shimada et al., 2004). As a humoral factor, Klotho works to 
Table 4. Primers information of the top 45 corresponding rat oligodendrocyte maturation-enriched genes

\begin{tabular}{|c|c|c|c|c|}
\hline Symbol & Accession no. & $\begin{array}{l}\text { Size } \\
\text { (bp) }\end{array}$ & Forward & Reverse \\
\hline Nod1 & NM_001109236 & 182 & GCTCGTCACAGACTCTGGTT & AAGGGTGGGAACTGATTCTC \\
\hline Ermn & NM_001008311 & 182 & TCTTCCACTGCCTTATTTGC & TGGGACAATGCTTACCTGAT \\
\hline Nipal4 & NM_001106995 & 198 & TCTCCGTTGACAACTTAGCC & GGTCCATGTGTCAAGCCTAC \\
\hline Opalin & NM_001017386 & 152 & CCGCTCTTCGGTATTTGTTA & AAGGACAAATGGTGTCCAGA \\
\hline Tmem125 & NM_001107967 & 198 & CCGTCAGAGATAAAGCCTCA & GAAGGGTTAGGGGTCAGGTA \\
\hline Prr5l & NM_001080150 & 231 & GTGGAGGAGAAGATCAAGCA & AGAAGGCAACTTGGACTGTG \\
\hline $\mathrm{Ndrl}$ & NM_001011991 & 151 & GGAAAGTTGGGCACCTTATT & CAGAAAAACAGGTTGCGAGT \\
\hline Трpр3 & NM_001009639 & 162 & AGGAGAGTTTCCGCAAGTTT & TTGCCTTGACTTTGGAGAAG \\
\hline Rab7b & NM_001109328 & 151 & GCAGGACTGGAAGAACTGAA & AGAGAGGTCTTTCCCACACC \\
\hline Mog & NM_022668 & 157 & GCGCTTCAACATTACGATCT & ACCCTGGCTC \\
\hline Ppp1r14a & NM_130 & 111 & ATGCC & ATTCA \\
\hline Ndrg1 & NM_001011991 & 151 & GGAAAGI & GCGAGT \\
\hline Mobp & NM_012720 & 104 & ATCACCCCAGAGATTCTTCC & GCATTGGAGCGAGAATTAAA \\
\hline Cldn11 & NM_053457 & 191 & САCCTCTTGGTTGCCTTAAA & ТАТTTСТСТСССААСССАCA \\
\hline Itih3 & & 160 & GGAA & GTCT \\
\hline Ttyh2 & XM_2 & 114 & ACCAT & CAGG \\
\hline Kndc1 & XM_O & 162 & CCTG & \\
\hline St18 & NM_1 & 213 & TTTA & ATAG \\
\hline Lpar1 & NM_05 & 213 & ATGT & CAGATGA \\
\hline Enpp6 & NM_OC & 194 & TCTCC & TGTAG \\
\hline Aspa & NM_024399 & 216 & CGTG & AAAGAA \\
\hline Mag & NM_01 & 154 & AACCT & TCACG \\
\hline & & 254 & TCTA & \\
\hline Pdlim2 & NM_- & 246 & AGAT & TGTCA \\
\hline Sgk2 & NM_1 & 299 & AACA & CCAAT \\
\hline Mgp & NM_0 & 298 & & CGACTGT \\
\hline Apod & & 190 & & \\
\hline S1pr5 & & 166 & AAAACGA & CAACC \\
\hline Nkain2 & & 179 & & \\
\hline Adamts4 & NM_O & 114 & CCAT & GGTC \\
\hline Efhd1 & NM_001109310 & 168 & GAACT & AGCAGGACTATGC \\
\hline Adssl1 & XM_001072867 & 242 & AАCTTACT & GACCATGGAGTGCCTCATAC \\
\hline Plekhh1 & NM_001108036 & 126 & GCCTAATCCAGCTCCTTTTC & ATGTTGGTTCCCAGACTTGA \\
\hline Gpr62 & XM_576464 & 101 & TCTGGGCAGAAGA & CTGGAGGGGTCCTCAGTTAT \\
\hline Plp1 & NM_030 & 206 & & GCAAAG \\
\hline Gjc2 & NM_001100784 & 244 & GAACT & AGGTC \\
\hline Unc5b & NM_0222207 & 170 & CGAATACGAGAGGTGCAGAT & AGAGGCTCCTGGTCAAAGTT \\
\hline Ca2 & NM_019291 & 129 & TGTCAGCAGTGAGCAGATGT & AAGGACGCCTTGATCTTTCT \\
\hline Hapln2 & NM_022285 & 124 & CCATCTTGAGAGCCTCTTCC & GCACGCCTTAGTACTGCAAG \\
\hline If & & 178 & CAAGCCTCTTGAGAAAGCTG & САСАТСТССАССТССАТСТС \\
\hline Mal & & 203 & & TCCAGTGTGATCCAGGAAGT \\
\hline I|23a & NM_130410 & 237 & GCTTTGGCCAGAATCTGTAA & САAАATTTСССТTСССАСT \\
\hline Mbp & NM_001025291 & 236 & TGGCCACTTCTCACTTTAGG & AGGTGTCCGTGGACATTAGA \\
\hline Bace2 & NM_001002802 & 185 & CCAAAAGGCTTCAACAGCTC & ATGTCCGGAATTTTTGCTTG \\
\hline Cxc112 & NM_022177 & 243 & GAGGCTCCTTTTTCCAGTTC & CCAAGTGAGAGGAAAGCAAA \\
\hline
\end{tabular}

promote expression of differentiation markers in 3T3-L1 cells, indicating that Klotho may play an essential role in adipocyte differentiation (Chihara et al., 2006).

In conclusion, we demonstrate a novel function of Klotho in oligodendrocyte maturation and developmental myelination of the CNS. This role is in addition to Klotho's function as a neuroprotective factor through preventing neurons from oxidative damage as proposed previously (Kuro-o, 2008b). Klotho may function as a humoral factor secreted by neurons or choroid plexus to promote myelination in neurodevelopment. It is possible that Klotho plays a regulatory role in maintaining or supporting oligodendrocyte and OPC function in the adult CNS, once the development has plateaued. Because we observed downregulation of Klotho in aged brain white matter, it is plausible that reduced Klotho level may account for damage to myelin and age-associated cognitive decline, and increasing Klotho level may protect myelin integrity and prevent myelin degeneration in the aged brain. Klotho is thus a new member of the large family of proteins that are crucial to neuron-oligodendrocyte communication, and studies on the functions of Klotho are likely to provide new therapeutic approaches for diseases in which myelin abnormalities play important pathogenic roles, such as multiple sclerosis and schizophrenia (Edgar et al., 2004; Taveggia et al., 2010).

\section{References}

Ahn SM, Byun K, Kim D, Lee K, Yoo JS, Kim SU, Jho EH, Simpson RJ, Lee B (2008) Olig2-induced neural stem cell differentiation involves downregulation of Wnt signaling and induction of Dickkopf-1 expression. PLoS One 3:e3917. CrossRef Medline

Arking DE, Becker DM, Yanek LR, Fallin D, Judge DP, Moy TF, Becker LC, Dietz HC (2003) KLOTHO allele status and the risk of early-onset occult coronary artery disease. Am J Hum Genet 72:1154-1161. CrossRef Medline

Arking DE, Atzmon G, Arking A, Barzilai N, Dietz HC (2005) Association between a functional variant of the KLOTHO gene and high-density lipoprotein cholesterol, blood pressure, stroke, and longevity. Circ Res 96:412-418. CrossRef Medline

Bansal R, Magge S, Winkler S (2003) Specific inhibitor of FGF receptor signaling: FGF-2-mediated effects on proliferation, differentiation, and MAPK activation are inhibited by PD173074 in oligodendrocyte-lineage cells. J Neurosci Res 74:486-493. CrossRef Medline

Baron W, Metz B, Bansal R, Hoekstra D, de Vries H (2000) PDGF and FGF-2 signaling in oligodendrocyte progenitor cells: regulation of proliferation and differentiation by multiple intracellular signaling pathways. Mol Cell Neurosci 15:314-329. CrossRef Medline

Bhat NR, Zhang P (1996) Activation of mitogen-activated protein kinases in oligodendrocytes. J Neurochem 66:1986-1994. CrossRef Medline

Bibollet-Bahena O, Almazan G (2009) IGF-1-stimulated protein synthesis in oligodendrocyte progenitors requires PI3K/mTOR/Akt and MEK/ERK pathways. J Neurochem 109:1440-1451. CrossRef Medline

Bibollet-Bahena O, Cui QL, Almazan G (2009) The insulin-like growth factor-1 axis and its potential as a therapeutic target in central nervous system (CNS) disorders. Cent Nerv Syst Agents Med Chem 9:95-109. Medline

Bloch L, Sineshchekova O, Reichenbach D, Reiss K, Saftig P, Kuro-o M, Kaether C (2009) Klotho is a substrate for $\alpha$-, $\beta$ - and $\gamma$-secretase. FEBS Lett 583:3221-3224. CrossRef Medline

Bowley MP, Cabral H, Rosene DL, Peters A (2010) Age changes in myelinated nerve fibers of the cingulate bundle and corpus callosum in the rhesus monkey. J Comp Neurol 518:3046-3064. CrossRef Medline

Bromberg J, Darnell JE Jr (2000) The role of STATs in transcriptional control and their impact on cellular function. Oncogene 19:2468-2473. CrossRef Medline

Bryant MR, Marta CB, Kim FS, Bansal R (2009) Phosphorylation and lipid raft association of fibroblast growth factor receptor-2 in oligodendrocytes. Glia 57:935-946. CrossRef Medline

Cahoy JD, Emery B, Kaushal A, Foo LC, Zamanian JL, Christopherson KS, Xing Y, Lubischer JL, Krieg PA, Krupenko SA, Thompson WJ, Barres BA (2008) A transcriptome database for astrocytes, neurons, and oligodendrocytes: a new resource for understanding brain development and function. J Neurosci 28:264-278. CrossRef Medline

Chateau MT, Araiz C, Descamps S, Galas S (2010) Klotho interferes with a novel FGF-signalling pathway and insulin/IGF-like signalling to improve longevity and stress resistance in Caenorhabditis elegans. Aging (Albany NY) 2:567-581. Medline

Chen CD, Podvin S, Gillespie E, Leeman SE, Abraham CR (2007) Insulin stimulates the cleavage and release of the extracellular domain of Klotho by ADAM10 and ADAM17. Proc Natl Acad Sci U S A 104:19796-19801. CrossRef Medline

Chihara Y, Rakugi H, Ishikawa K, Ikushima M, Maekawa Y, Ohta J, Kida I, Ogihara T (2006) Klotho protein promotes adipocyte differentiation. Endocrinology 147:3835-3842. CrossRef Medline

Cui QL, Almazan G (2007) IGF-I-induced oligodendrocyte progenitor proliferation requires PI3K/Akt, MEK/ERK, and Src-like tyrosine kinases. J Neurochem 100:1480-1493. CrossRef Medline

Deary IJ, Harris SE, Fox HC, Hayward C, Wright AF, Starr JM, Whalley LJ 
(2005) KLOTHO genotype and cognitive ability in childhood and old age in the same individuals. Neurosci Lett 378:22-27. CrossRef Medline

Dell'Albani P, Kahn MA, Cole R, Condorelli DF, Giuffrida-Stella AM, de Vellis J (1998) Oligodendroglial survival factors, PDGF-AA and CNTF, activate similar JAK/STAT signaling pathways. J Neurosci Res 54:191205. CrossRef Medline

Du Y, Lercher LD, Zhou R, Dreyfus CF (2006) Mitogen-activated protein kinase pathway mediates effects of brain-derived neurotrophic factor on differentiation of basal forebrain oligodendrocytes. J Neurosci Res 84: 1692-1702. CrossRef Medline

Duce JA, Podvin S, Hollander W, Kipling D, Rosene DL, Abraham CR (2008) Gene profile analysis implicates Klotho as an important contributor to aging changes in brain white matter of the rhesus monkey. Glia 56:106117. CrossRef Medline

Dugandzija-Novakoviæ S, Koszowski AG, Levinson SR, Shrager P (1995) Clustering of $\mathrm{Na}^{+}$channels and node of Ranvier formation in remyelinating axons. J Neurosci 15:492-503. Medline

Edgar JM, McLaughlin M, Barrie JA, McCulloch MC, Garbern J, Griffiths IR (2004) Age-related axonal and myelin changes in the rumpshaker mutation of the Plp gene. Acta Neuropathol 107:331-335. CrossRef Medline

Fancy SP, Baranzini SE, Zhao C, Yuk DI, Irvine KA, Kaing S, Sanai N, Franklin RJ, Rowitch DH (2009) Dysregulation of the Wnt pathway inhibits timely myelination and remyelination in the mammalian CNS. Genes Dev 23:1571-1585. CrossRef Medline

Feigenson K, Reid M, See J, Crenshaw EB 3rd, Grinspan JB (2009) Wnt signaling is sufficient to perturb oligodendrocyte maturation. Mol Cell Neurosci 42:255-265. CrossRef Medline

Fortin D, Rom E, Sun H, Yayon A, Bansal R (2005) Distinct fibroblast growth factor (FGF)/FGF receptor signaling pairs initiate diverse cellular responses in the oligodendrocyte lineage. J Neurosci 25:7470-7479. CrossRef Medline

Foster PP, Rosenblatt KP, Kuljiš RO (2011) Exercise-induced cognitive plasticity, implications for mild cognitive impairment and Alzheimer's disease. Front Neurol 2:28. CrossRef Medline

Frederick TJ, Min J, Altieri SC, Mitchell NE, Wood TL (2007) Synergistic induction of cyclin D1 in oligodendrocyte progenitor cells by IGF-I and FGF-2 requires differential stimulation of multiple signaling pathways. Glia 55:1011-1022. CrossRef Medline

Frost EE, Zhou Z, Krasnesky K, Armstrong RC (2009) Initiation of oligodendrocyte progenitor cell migration by a PDGF-A activated extracellular regulated kinase (ERK) signaling pathway. Neurochem Res 34:169-181. CrossRef Medline

Furusho M, Dupree JL, Nave KA, Bansal R (2012) Fibroblast growth factor receptor signaling in oligodendrocytes regulates myelin sheath thickness. J Neurosci 32:6631-6641. CrossRef Medline

Fyffe-Maricich SL, Karlo JC, Landreth GE, Miller RH (2011) The ERK2 mitogen-activated protein kinase regulates the timing of oligodendrocyte differentiation. J Neurosci 31:843-850. CrossRef Medline

Guardiola-Diaz HM, Ishii A, Bansal R (2012) Erk1/2 MAPK and mTOR signaling sequentially regulates progression through distinct stages of oligodendrocyte differentiation. Glia 60:476-486. CrossRef Medline

Hanafy KA, Sloane JA (2011) Regulation of remyelination in multiple sclerosis. FEBS Lett 585:3821-3828. CrossRef Medline

He Y, Dupree J, Wang J, Sandoval J, Li J, Liu H, Shi Y, Nave KA, CasacciaBonnefil P (2007) The transcription factor Yin Yang 1 is essential for oligodendrocyte progenitor differentiation. Neuron 55:217-230. CrossRef Medline

Hinman JD, Abraham CR (2007) What's behind the decline? The role of white matter in brain aging. Neurochem Res 32:2023-2031. CrossRef Medline

Hsieh CC, Kuro-o M, Rosenblatt KP, Brobey R, Papaconstantinou J (2010) The ASK1-Signalosome regulates $\mathrm{p} 38$ MAPK activity in response to levels of endogenous oxidative stress in the Klotho mouse models of aging. Aging (Albany NY) 2:597-611. Medline

Imura A, Iwano A, Tohyama O, Tsuji Y, Nozaki K, Hashimoto N, Fujimori T, Nabeshima Y (2004) Secreted Klotho protein in sera and CSF: implication for post-translational cleavage in release of Klotho protein from cell membrane. FEBS Lett 565:143-147. CrossRef Medline

Ishii A, Fyffe-Maricich SL, Furusho M, Miller RH, Bansal R (2012) ERK1/ ERK2 MAPK signaling is required to increase myelin thickness independent of oligodendrocyte differentiation and initiation of myelination. J Neurosci 32:8855-8864. CrossRef Medline
Kawaguchi H, Manabe N, Miyaura C, Chikuda H, Nakamura K, Kuro-o M (1999) Independent impairment of osteoblast and osteoclast differentiation in klotho mouse exhibiting low-turnover osteopenia. J Clin Invest 104:229-237. CrossRef Medline

King GD, Rosene DL, Abraham CR (2012) Promoter methylation and agerelated downregulation of Klotho in rhesus monkey. Age (Dordr) 34: 1405-1419. CrossRef Medline

Kioussi C, Gross MK, Gruss P (1995) Pax3: a paired domain gene as a regulator in PNS myelination. Neuron 15:553-562. CrossRef Medline

Kohama SG, Rosene DL, Sherman LS (2012) Age-related changes in human and non-human primate white matter: from myelination disturbances to cognitive decline. Age (Dordr) 34:1093-1110. CrossRef Medline

Kuro-o M (2006) Klotho as a regulator of fibroblast growth factor signaling and phosphate/calcium metabolism. Curr Opin Nephrol Hypertens 15: 437-441. CrossRef Medline

Kuro-o M (2008a) Endocrine FGFs and Klothos: emerging concepts. Trends Endocrinol Metab 19:239-245. CrossRef Medline

Kuro-o M (2008b) Klotho as a regulator of oxidative stress and senescence. Biol Chem 389:233-241. CrossRef Medline

Kuro-o M (2010) Klotho. Pflugers Arch 459:333-343. CrossRef Medline

Kuro-o M, Matsumura Y, Aizawa H, Kawaguchi H, Suga T, Utsugi T, Ohyama Y, Kurabayashi M, Kaname T, Kume E, Iwasaki H, Iida A, Shiraki-Iida T, Nishikawa S, Nagai R, Nabeshima YI (1997) Mutation of the mouse klotho gene leads to a syndrome resembling ageing. Nature 390:45-51. CrossRef Medline

Kurosu H, Yamamoto M, Clark JD, Pastor JV, Nandi A, Gurnani P, McGuinness OP, Chikuda H, Yamaguchi M, Kawaguchi H, Shimomura I, Takayama Y, Herz J, Kahn CR, Rosenblatt KP, Kuro-o M (2005) Suppression of aging in mice by the hormone Klotho. Science 309:1829 1833. CrossRef Medline

Kurosu H, Ogawa Y, Miyoshi M, Yamamoto M, Nandi A, Rosenblatt KP, Baum MG, Schiavi S, Hu MC, Moe OW, Kuro-o M (2006) Regulation of fibroblast growth factor-23 signaling by klotho. J Biol Chem 281:61206123. CrossRef Medline

Li SA, Watanabe M, Yamada H, Nagai A, Kinuta M, Takei K (2004) Immunohistochemical localization of Klotho protein in brain, kidney, and reproductive organs of mice. Cell Struct Funct 29:91-99. CrossRef Medline

Liu F, Wu S, Ren H, Gu J (2011) Klotho suppresses RIG-I-mediated senescence-associated inflammation. Nat Cell Biol 13:254-262. CrossRef Medline

Liu H, Fergusson MM, Castilho RM, Liu J, Cao L, Chen J, Malide D, Rovira II, Schimel D, Kuo CJ, Gutkind JS, Hwang PM, Finkel T (2007) Augmented Wnt signaling in a mammalian model of accelerated aging. Science 317:803-806. CrossRef Medline

Maekawa Y, Ohishi M, Ikushima M, Yamamoto K, Yasuda O, Oguro R, Yamamoto-Hanasaki H, Tatara Y, Takeya Y, Rakugi H (2011) Klotho protein diminishes endothelial apoptosis and senescence via a mitogenactivated kinase pathway. Geriatr Gerontol Int 11:510-516. CrossRef Medline

Makris N, Papadimitriou GM, van der Kouwe A, Kennedy DN, Hodge SM, Dale AM, Benner T, Wald LL, Wu O, Tuch DS, Caviness VS, Moore TL, Killiany RJ, Moss MB, Rosene DL (2007) Frontal connections and cognitive changes in normal aging rhesus monkeys: a DTI study. Neurobiol Aging 28:1556-1567. CrossRef Medline

Mason JL, Toews A, Hostettler JD, Morell P, Suzuki K, Goldman JE, Matsushima GK (2004) Oligodendrocytes and progenitors become progressively depleted within chronically demyelinated lesions. J Pathol 164: 1673-1682. Medline

Massa PT, Saha S, Wu C, Jarosinski KW (2000) Expression and function of the protein tyrosine phosphatase SHP-1 in oligodendrocytes. Glia 29: 376-385. CrossRef Medline

Meakin SO, MacDonald JI, Gryz EA, Kubu CJ, Verdi JM (1999) The signaling adapter FRS-2 competes with Shc for binding to the nerve growth factor receptor TrkA: a model for discriminating proliferation and differentiation. J Biol Chem 274:9861-9870. CrossRef Medline

Medici D, Razzaque MS, Deluca S, Rector TL, Hou B, Kang K, Goetz R, Mohammadi M, Kuro-o M, Olsen BR, Lanske B (2008) FGF-23-Klotho signaling stimulates proliferation and prevents vitamin D-induced apoptosis. J Cell Biol 182:459-465. CrossRef Medline

Mi S, Miller RH, Lee X, Scott ML, Shulag-Morskaya S, Shao Z, Chang J, Thill G, Levesque M, Zhang M, Hession C, Sah D, Trapp B, He Z, Jung V, 
McCoy JM, Pepinsky RB (2005) LINGO-1 negatively regulates myelination by oligodendrocytes. Nat Neurosci 8:745-751. CrossRef Medline

Nagai R, Saito Y, Ohyama Y, Aizawa H, Suga T, Nakamura T, Kurabayashi M, Kuroo M (2000) Endothelial dysfunction in the klotho mouse and downregulation of klotho gene expression in various animal models of vascular and metabolic diseases. Cell Mol Life Sci 57:738-746. CrossRef Medline

Nagai T, Yamada K, Kim HC, Kim YS, Noda Y, Imura A, Nabeshima Y, Nabeshima T (2003) Cognition impairment in the genetic model of aging klotho gene mutant mice: a role of oxidative stress. FASEB J 17:50-52. CrossRef Medline

Ogawa Y, Schafer DP, Horresh I, Bar V, Hales K, Yang Y, Susuki K, Peles E, Stankewich MC, Rasband MN (2006) Spectrins and ankyrinB constitute a specialized paranodal cytoskeleton. J Neurosci 26:5230-5239. CrossRef Medline

Oh SY, Chen CD, Abraham CR (2010) Cell-type dependent modulation of Notch signaling by the amyloid precursor protein. J Neurochem 113:262274. CrossRef Medline

Ong SH, Guy GR, Hadari YR, Laks S, Gotoh N, Schlessinger J, Lax I (2000) FRS2 proteins recruit intracellular signaling pathways by binding to diverse targets on fibroblast growth factor and nerve growth factor receptors. Mol Cell Biol 20:979-989. CrossRef Medline

Peters A (2009) The effects of normal aging on myelinated nerve fibers in monkey central nervous system. Front Neuroanat 3:11. CrossRef Medline

Rakugi H, Matsukawa N, Ishikawa K, Yang J, Imai M, Ikushima M, Maekawa Y, Kida I, Miyazaki J, Ogihara T (2007) Anti-oxidative effect of Klotho on endothelial cells through cAMP activation. Endocrine 31:82-87. CrossRef Medline

Rasband MN, Kagawa T, Park EW, Ikenaka K, Trimmer JS (2003) Dysregulation of axonal sodium channel isoforms after adult-onset chronic demyelination. J Neurosci Res 73:465-470. CrossRef Medline

Repa JJ, Mangelsdorf DJ (2000) The role of orphan nuclear receptors in the regulation of cholesterol homeostasis. Annu Rev Cell Dev Biol 16:459481. CrossRef Medline

Rosene DL, Roy NJ, Davis BJ (1986) A cryoprotection method that facilitates cutting frozen sections of whole monkey brains for histological and histochemical processing without freezing artifact. J Histochem Cytochem 34:1301-1315. CrossRef Medline

Shih PH, Yen GC (2007) Differential expressions of antioxidant status in aging rats: the role of transcriptional factor Nrf2 and MAPK signaling pathway. Biogerontology 8:71-80. CrossRef Medline

Shimada T, Takeshita Y, Murohara T, Sasaki K, Egami K, Shintani S, Katsuda Y, Ikeda H, Nabeshima Y, Imaizumi T (2004) Angiogenesis and vasculogenesis are impaired in the precocious-aging klotho mouse. Circulation 110:1148-1155. CrossRef Medline

Shiozaki M, Yoshimura K, Shibata M, Koike M, Matsuura N, Uchiyama Y, Gotow T (2008) Morphological and biochemical signs of age-related neurodegenerative changes in klotho mutant mice. Neuroscience 152: 924-941. CrossRef Medline

Sloane JA, Vartanian TK (2007) Myosin Va controls oligodendrocyte morphogenesis and myelination. J Neurosci 27:11366-11375. CrossRef Medline

Sloane JA, Hinman JD, Lubonia M, Hollander W, Abraham CR (2003) Agedependent myelin degeneration and proteolysis of oligodendrocyte proteins is associated with the activation of calpain-1 in the rhesus monkey. J Neurochem 84:157-168. CrossRef Medline

Subramanian A, Tamayo P, Mootha VK, Mukherjee S, Ebert BL, Gillette MA, Paulovich A, Pomeroy SL, Golub TT, Lander ES, Mesirov JP (2005) Gene set enrichment analysis: a knowledge-based approach for interpret- ing genome-wide expression profiles. Proc Natl Acad Sci U S A 102: 15545-15550. CrossRef Medline

Taveggia C, Feltri ML, Wrabetz L (2010) Signals to promote myelin formation and repair. Nat Rev Neurol 6:276-287. CrossRef Medline

Thurston RD, Larmonier CB, Majewski PM, Ramalingam R, Midura-Kiela M, Laubitz D, Vandewalle A, Besselsen DG, Mühlbauer M, Jobin C, Kiela PR, Ghishan FK (2010) Tumor necrosis factor and interferon-gamma down-regulate Klotho in mice with colitis. Gastroenterology 138:13841394; 1394.e1-1394.e2. CrossRef Medline

Trapp BD, Kidd GJ (2004) Structure of the myelinated axon. In: Myelin biology and disorders (Lazzarini RA, ed), pp 3-22. London: Elsevier Academic.

Urakawa I, Yamazaki Y, Shimada T, Iijima K, Hasegawa H, Okawa K, Fujita T, Fukumoto S, Yamashita T (2006) Klotho converts canonical FGF receptor into a specific receptor for FGF23. Nature 444:770-774. CrossRef Medline

Vabnick I, Novakoviæ SD, Levinson SR, Schachner M, Shrager P (1996) The clustering of axonal sodium channels during development of the peripheral nervous system. J Neurosci 16:4914-4922. Medline

Van't Veer A, Du Y, Fischer TZ, Boetig DR, Wood MR, Dreyfus CF (2009) Brain-derived neurotrophic factor effects on oligodendrocyte progenitors of the basal forebrain are mediated through trkB and the MAP kinase pathway. J Neurosci Res 87:69-78. CrossRef Medline

Wang L, Schuster GU, Hultenby K, Zhang Q, Andersson S, Gustafsson JA (2002) Liver $\times$ receptors in the central nervous system: from lipid homeostasis to neuronal degeneration. Proc Natl Acad Sci U S A 99:1387813883. CrossRef Medline

Waxman SG (1998) Demyelinating diseases: new pathological insights, new therapeutic targets. N Engl J Med 338:323-325. CrossRef Medline

Wegner M (2000) Transcriptional control in myelinating glia: the basic recipe. Glia 29:118-123. CrossRef Medline

Whitney KD, Watson MA, Collins JL, Benson WG, Stone TM, Numerick MJ, Tippin TK, Wilson JG, Winegar DA, Kliewer SA (2002) Regulation of cholesterol homeostasis by the liver $\times$ receptors in the central nervous system. Mol Endocrinol 16:1378-1385. CrossRef Medline

Wisco JJ, Killiany RJ, Guttmann CR, Warfield SK, Moss MB, Rosene DL (2008) An MRI study of age-related white and gray matter volume changes in the rhesus monkey. Neurobiol Aging 29:1563-1575. CrossRef Medline

Wolf I, Levanon-Cohen S, Bose S, Ligumsky H, Sredni B, Kanety H, Kuro-o M, Karlan B, Kaufman B, Koeffler HP, Rubinek T (2008) Klotho: a tumor suppressor and a modulator of the IGF-1 and FGF pathways in human breast cancer. Oncogene 27:7094-7105. CrossRef Medline

Yamamoto M, Clark JD, Pastor JV, Gurnani P, Nandi A, Kurosu H, Miyoshi M, Ogawa Y, Castrillon DH, Rosenblatt KP, Kuro-o M (2005) Regulation of oxidative stress by the anti-aging hormone klotho. J Biol Chem 280:38029-38034. CrossRef Medline

Younes-Rapozo V, Felgueiras LO, Viana NL, Fierro IM, Barja-Fidalgo C, Manhães AC, Barradas PC (2009) A role for the MAPK/ERK pathway in oligodendroglial differentiation in vitro: stage specific effects on cell branching. Int J Dev Neurosci 27:757-768. CrossRef Medline

Zeldich E, Koren R, Nemcovsky C, Weinreb M (2007) Enamel matrix derivative stimulates human gingival fibroblast proliferation via ERK. J Dent Res 86:41-46. CrossRef Medline

Zhao Y, Banerjee S, Dey N, LeJeune WS, Sarkar PS, Brobey R, Rosenblatt KP, Tilton RG, Choudhary S (2011) Klotho depletion contributes to increased inflammation in kidney of the $\mathrm{db} / \mathrm{db}$ mouse model of diabetes via RelA (serine)536 phosphorylation. Diabetes 60:1907-1916. CrossRef Medline 